Irade $\begin{array}{lll}\text { World } \\ \text { institute }\end{array}$

\title{
Pacific Alliance: An Opportunity to Establish New Priorities on the Protection of Intellectual Property in Free Trade Agreements
}

\author{
John Cusipuma \\ Pontificia Universidad Católica del Perú \\ john.cusipuma@pucp.pe \\ Gonzalo Ramírez \\ Pontificia Universidad Católica del Perú \\ gonzaloramirez@fv-legal.com
}

The objective of this working paper is to demonstrate that the Pacific Alliance constitutes an opportunity for the Parties of this process, to separate themselves from the schemes established in past negotiations regarding the protection of Intellectual Property Rights, in order to build a new agenda that addresses primarily the main concerns that these Parties have on this field, as could be, among other concerns, those referring to the protection of traditional knowledge.

Research for this paper was funded by the Swiss State Secretariat for Economic Affairs under the SECO / WTI Academic Cooperation Project, based at the World Trade Institute of the University of Bern, Switzerland.

SECO working papers are preliminary documents posted on the WTI website (www.wti.org) and widely circulated to stimulate discussion and critical comment. These papers have not been formally edited. Citations should refer to a "SECO / WTI Academic Cooperation Project" paper with appropriate reference made to the author(s).

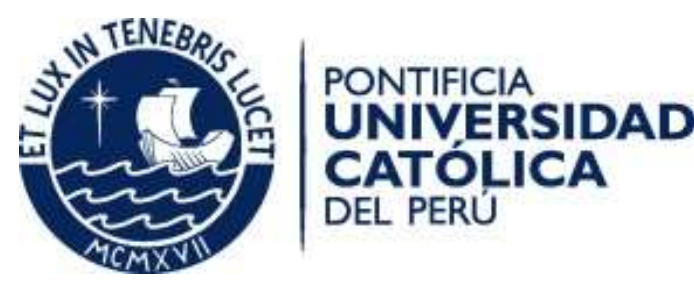




\title{
PACIFIC ALLIANCE (ALIANZA DEL PACÍFICO): AN OPPORTUNITY TO ESTABLISH NEW PRIORITIES ON THE PROTECTION OF INTELLECTUAL PROPERTY IN FREE TRADE AGREEMENTS
}

\author{
John Cusipuma* \\ Gonzalo Ramirez ${ }^{\dagger}$
}

\section{INTRODUCTION}

Latin America has begun a process of integration that has called the attention of diverse actors in different areas, including political, economic and academic. That is because the Pacific Alliance is composed of countries that had an important economic growth in the region over the recent years (Chile, Colombia Mexico and Peru) and that have shown a strong commitment to liberalize trade in a context of world economic crisis that these countries have been able to face by opening and diversifying its respective international markets.

This self-called process of deep integration, not only constitutes a space searching trade liberalization, but also, a mechanism of political and commercial integration that serves as a main objective to reach the free circulation of goods, services and investments, to improve the competitiveness of its economies, and to impel its growth and development.

In this regard, the members of the Pacific Alliance have been working for the purpose of materializing the above mentioned objectives. Thus, they have signed the Framework Agreement of the Pacific Alliance that gathers the economic, political and commercial character of the block; and the Additional Protocol to the Framework Agreement of the Pacific Alliance, which prioritizes the integration and the liberalization in the setting of trade.

Regarding the matters contained on those Agreements, draws the attention that the members of the Pacific Alliance have decided not to develop the aspects of intellectual property protection in the Additional Protocol of the Framework of the Pacific Alliance. Therefore, because these countries have international trade agreements that have included this matter, that gives to the Pacific Alliance members similar standards of protection of intellectual property, as well as the fact that, from our perspective, these countries share similar interests and concerns about the protection of intellectual property rights, like we will explain in this paper, which could have been met within the framework of the Pacific Alliance.

\footnotetext{
* Mr. John Cusipuma is the chief coordinator of the Trade Remedies and Competition Policy Area of the Ministry of Foreign Trade and Tourism of Peru since 2014. Currently, he is also the lead of the Intellectual Property Legal Scrub of the Transpacific Partnership Agreement (TPP). Prior to this position Mr. Cusipuma served as legal adviser at the Antidumping Authority of Peru and on the Legal Advisory of the Vice Ministry of Foreign Trade of Peru. Mr. Cusipuma holds a Law Degree from San Martín de Porres University, a Master in Economic International Law and a Master in Political Sciences with a concentration in International Relations from the Pontifical Catholic University of Peru.

${ }^{\dagger}$ Mr. Gonzalo Ramirez is the Head of the Intellectual Property Area at the Fernandez \& Vargas Law Firm since March 2013. Prior to this position, Mr. Ramirez served in the private and the public sector as legal adviser with an experience of eleven years in Intellectual Property law. Mr. Ramirez holds a Law Degree from the Pontifical Catholic University of Peru and a Master in Business Law from the same university.
} 
The interest of the countries to look for an international framework to the protection of intellectual property rights started in the late XIX century. However, in the international trade field it was recently featured an international standard in 1994 with the emergence of the World Trade Organization (WTO) and the Agreement on Aspects of Intellectual Property Rights Related to Trade (TRIPs Agreement). Later, the intellectual property topics have been deepened under schemes of bilateral international trade agreements encouraged especially by the United States of America, European Union and Japan, aiming to protect their own industries.

In that sense, considering the importance of the Pacific Alliance and of its intra-regional and global projection, emphasizing the Asia Pacific region, it is a particular interest to be able to analyse what are the points the block should bear in mind to establish obligations on the intellectual property matters that will attend its interests. Although these obligations have not been established, it has formed a working group that will mandate the elaborate work plan on the aspects of the intellectual property.

For that reason, the current work will present the common aspects of the intellectual property matter that the founding countries of the Pacific Alliance share, which includes some of the problems these countries are facing regarding this matter, as well as the point of interests that they could boost in the frame of the Pacific Alliance. We will also address the question of whether such issues should be discussed in the context of cooperation or if it is appropriate and necessary to articulate obligations at the international level which allows them to address this problem and address those interests.

From our perspective there are conditions that exist in the framework of the Pacific Alliance that can make favourable to adopt actions before the accession of new members to these integration processes in the following years. 


\section{A PRAGMATIC PROCESS OF INTEGRATION}

The Pacific Alliance has turned into one of the processes of integration that has called the attention of several developed and developing countries, due to the dynamic economies of the countries that takes part of it. And the fact that Chile, Colombia, Mexico and Peru, founders of the Pacific Alliance, have shown and sustain economic growth in the last years and have solid conviction by taking risk and opening its market, and makes it different from all other processes of Integration like the Common Market of the South (MERCOSUR, for initials in Spanish), the Andean Community (CAN, for initials in Spanish) and the Union of South American Nations (UNASUR, for initials in Spanish).

The history of the emergence of this process of integration goes back to the formation of the Arch of Latin-American Pacific which was started by Chile, Colombia, Costa Rica, Ecuador, El Salvador, Guatemala, Honduras, Mexico, Nicaragua, Panama and Peru during the First Presidents' Summit held in San Salvador, El Salvador in October, $2008^{1}$. This commercial space of coordination, driven mainly by Colombia, aims the implementation of measures to promote trade and economic integration, as well as create a meeting space between the countries of the Latin America and Asia Pacific $\operatorname{Rim}^{2}$

Despite of the great interest and efforts made by the counties from the Arch of the Pacific to finalize mechanisms that will promote trade and investment, there were no concrete results obtained, because once again it was evident in Latin America the existence of distinct positions in relation to economic models and trade integration that each of these countries consider important to develop in the search for economic improvement for its citizens.

Of the Arch Pacific countries, Chile, Colombia, Mexico and Peru clearly highlighted having a common vision on how to integrate with the world. Initially, these countries showed a close tie on foreign economic policy to United States of America ${ }^{3}$ and a clear conviction to leave the import substitution model in the past, to strengthen the opening of international markets ${ }^{4}$, like limiting the state intervention in the economy. Additionally Chile, Colombia and Peru were trying to develop the idea to become the open doors for Asia to get into Latin America which was reflected when Chile and Peru started its participation in the Asia Pacific Economic Conference (APEC) and Trans Pacific Partnership Agreement (TPP) which Mexico later joined.

In addition, these four countries have signed international trade agreements between them. Peru signed with Chile a Free Trade Agreement on August 22, 2006 and with Mexico a Commercial Integration Agreement on April 6, 2011. Chile (one of the first few countries who signed this kind of treaties) has signed a Free Trade Agreement with Mexico and Colombia on April 17, 1998 and November 27, 2006 respectively. Colombia and Mexico signed a Free Trade Agreement on June 13, 1994.

Considering the conditions of convergence that these countries were showing with regards to its economic growth and commercial opening, in the city of Lima, on April

\footnotetext{
Before the achievement of this Summit, it announced the launch the Arch of the Pacific in the First Forum of Secretaries of Commerce carried out in Cali, Colombia in January, 2007.

${ }^{2}$ GARCÍA, Jaime. "Pacific Alliance. Where do we go?" International agenda Year XX, N ` 31, 2013, Lima, p. 43. (Author translation, original in Spanish).

${ }^{3}$ Chile, Colombia, Mexico and Peru signed free-trade agreements with the United States, respectively, on June 6, 2003, November 22, 2006, December 17, 1992 and April 12, 2006.

${ }^{4}$ Guerra, Angélica. "An approach "inside-out" to the Peruvian economic foreign policy". In Pacific Alliance Myths and realities, University Santiago de Cali, Cali, 2014, p.224. (Author translation, original in Spanish).
} 
28, 2011, they signed the Presidential Declaration of the Pacific Alliance, in order to establish a Deep Integration Area on the frame of the Latin America Pacific Arch among Chile, Colombia, Mexico and Peru (whose participation was highlighted to sum up this new type of trade integration), and having Panamá as the first observer of this process 5 .

The Pacific Alliance has the following targets: i) to construct an area of deep integration to advance progressively towards the free circulation of goods, services, capitals, people and economy; ii) drive major growth, economic development and economic competitiveness of its members, visualize the achievement of a greater well-being, overcome the socio economic inequalities and push the social inclusion of its inhabitants; and, iii) become a platform for political articulation, economic and commercial integration and projection to the world emphasizing the Asia-Pacific region. ${ }^{6}$

Based on these objectives, the Pacific Alliance is considered as an open integration process, nonexclusive, integrated by countries that share common interests and similar views on development and promotion of free trade, which also makes this integration forum geared towards modernization, pragmatism and political will to meet the challenges of the international economy.

The main priority of the technical groups that were constituted to implement the aspirations of the four founding countries, was directed to work on the matters related to the movement of business persons and the simplification for the migratory transit, trade facilitation, customs cooperation, cooperation in other areas of trade, investments, services, institutional issues and the establishment of a dispute settlement mechanism ${ }^{8}$.

The above-mentioned technical groups ${ }^{9}$ were supervised by the Group of High Level (GAN) which was shaped by the Vice-ministers of Foreign trade and Foreign Affairs. It is necessary to point out that inside the structure of the Pacific Alliance the decisions to meet the objectives and develop actions specifically planned according to the framework and presidential declarations are adopted to the level of the Cabinet of Foreign Trade and of Foreign Affairs. Also, periodically the Heads of State of the four countries carry out meetings for the purpose of checking the advances, to determine the orientation of this process of integration. ${ }^{10}$

Note that this integration process has three pillars (political, economic and commercial) which they were embodied in the Framework Agreement of the Pacific Alliance signed on June 6, 2012 on the occasion of the IV Presidential Summit of the Pacific Alliance held in Paranal, Chile. In addition to Panama, Costa Rica become an observer in October 2013.

\footnotetext{
${ }^{5}$ Prior to the signature of this Declaration, in October, 2010 the Area of Deep Integration was thrown between Colombia, Chile, Ecuador, Panama and Peru.

${ }^{6}$ In: https://alianzapacifico.net/que-es-la-alianza/\#la-alianza-del-pacifico-y-sus-objetivos (consulted on April 1, 2016).

7 PWC. "The Pacific Alliance a new age for Latin America", the first edition, Mexico, October, 2014, p.7. (Author translation, original in Spanish).

http://www.acuerdoscomerciales.gob.pe/index.php?option=com content\&view=category\&layout=blog\&id=166\&ltemid=1 85 (Consulted on April 1, 2016).

${ }^{9}$ In total they went so far as to constitute 20 technical groups on the following topics: entities of promotion, institutional issues, trade and integration, experts' committee CEAP, public buys, cooperation, mining development, education, communication strategy, innovation, regulative progress, persons' mobility, intellectual property, PYMES, relationship day pupil, services and capitals, fiscal transparency, tourism, gender and culture.

10 The Pacific Alliance is not provided with a Permanent Secretariat, for what annually the members' takes turn in order to carry out the coordination of the mechanism. In July 2015, Mexico transferred to Peru the presidency pro tempore of the Pacific Alliance.
} 
The important political component of the Pacific Alliance is reflected on the requirements imposed by the founding countries; these countries establish that for the accession of a new member to this integration process, that aspiring member must recognize the rule of law, democracy, separation of state powers, respect of human rights and fundamental freedoms. ${ }^{11}$

The interest and expectation that this block has generated is due not only to the aspirations that these countries have, but also because of the figures that support its decision to open to the world and especially to Asia. Thus, the Pacific Alliance is: i) the eighth largest economy and the eighth largest exporter worldwide; ii) in Latin America and the Caribbean, the group represents $38 \%$ of GDP, concentrated $50 \%$ of total trade and attracts $45 \%$ of foreign direct investment; and iii) in 2015, the four countries had a population of 216 million people and an average GDP of $\$ 9,910$ per capita. $^{12}$.

In this context, the countries of the Pacific Alliance have agreed to deduct $100 \%$ of tariffs of trade in goods which will be implemented immediately in relation to the $92 \%$ universal tariffs and within a maximum period of 17 years for the remaining $8 \%$.

All these components and figures of the block have caught the attention of many developed and developing countries, to date sums up to 42 observer countries among which is the United States, Canada, UK, China, South Korea, Japan, Australia, new Zealand, Uruguay, Ecuador, Honduras, Dominican Republic, and others. The observer countries of the Pacific Alliance can participate in the meetings to which they are invited with the consent of the member states and may be entitled to voice out their opinions out but not to vote. Of 42 observing countries, Costa Rica and Panama are the only ones considered candidates to be part of this process of Integration.

In addition to the participation of this significant number of observing countries, and highlighting the pragmatic character of this block, the member countries have allowed their respective private sectors to have an important participation, which was formalized in 2012, by establishing the Enterprise Council of the Pacific Alliance (CEAP). The important role of the business sector as a doer and operator of the integration process is recognized, as well as, the good coordination that exist between the sector and officials of each governments.

CEAP was created with the objective that this businessmen group assist their governments in identify obstacles or situations that have negative impact on trade flows between the countries of the Pacific Alliance. Specifically, the CEAP's work is direct to: i) the harmonization of technical standards and regulative coherence in such sectors like food, medicines and cosmetics; ii) to reach the certification level IV ${ }^{13}$ of sanitary authorities before the Pan-American Organization of Health; iii) to achieve the financial integration $^{14}$; iv) to impel the topics on public purchases; v) to encourage the recording of data and the innovation; vi) to reach the interconnection of the single windows of foreign trade; vii) to strengthen the promotion of supply chain; and viii) to improve the logistic competitiveness. ${ }^{15}$

The works mentioned about the topics above are presented to the High Level Group (GAN) of the Pacific Alliance, which analyses the feasibility of the proposals. The CEAP meets at least during the celebration of the presidential summits of the block

\footnotetext{
${ }^{11}$ Framework Agreement of the Pacific Alliance. - Article 2 Democracy and Rule of Law.

12 In: https://alianzapacifico.net/que-es-la-alianza/\#la-alianza-del-pacifico-y-sus-objetivos (consulted on April 2, 2016).

${ }^{13}$ Homologation of sanitary certificates.

${ }^{14}$ Unification of the stock exchanges.

${ }^{15}$ Targets of the Managerial Council of the Pacific Alliance. In PWC. "The Pacific Alliance a new age for Latin America", Mexico City, 2014, p. 10. (Author translation, original in Spanish).
} 
where they can present to the leaders of the four countries, the work that they have realized to boost the deep integration that it is expected.

Thanks to the joint work between the officials of the four member countries and the private sector, the block has reached an important advance in the commercial integration, what has turned out to be materialized across the Additional Protocol to the Framework Agreement of the Pacific Alliance. This Protocol, signed on February 10, 2014, and in force from May 1, 2016, constitutes the instrument that is going to allow the liberalization of $100 \%$ of the trade of goods ${ }^{16}$, and an improvement in the access of services and the attraction of investors.

Also, the above-mentioned Protocol supposes the deepening of the international trade agreements that the member countries have between themselves, since in addition to having developed with major depth existing obligations, there have been included new dispositions that offer major opportunities for the small and medium enterprises that think about how to insert in the chains of value in the regional and world environment, more specifically in the block Asia-Pacific ${ }^{17}$.

Nevertheless all that was mentioned, and as we will see in this document, the countries of the Pacific Alliance decided not to include a specific chapter on intellectual property, whereby some questions arise with regard to the need that in this block dispositions are included on the matter, considering its economic importance, having in consideration the common problems that they face and the interests that have on the subject of intellectual property, despite the subscription of trade agreements with other countries and economic blocks.

\footnotetext{
${ }^{16}$ As it was indicated $92 \%$ of the tariff universe will be liberalize since the entry into force of the Protocol and in 17 years the remaining $8 \%$.

7 The Additional Protocol to the Framework Agreement of the Pacific Alliance is provided with 19 chapters: Initial provisions, general definitions, market access, rules of origin and procedures related to the origin, trade facilitation and customs cooperation; sanitary and phytosanitary measures, technical obstacles to trade, public hiring, cross-border services trade, investment, financial services, marine services, electronic commerce, telecommunications, transparency, administration of the additional protocol, dispute settlement, exceptions, final provisions.
} 


\section{INTELLECTUAL PROPERTY IN INTERNATIONAL TRADE AGREEMENTS}

Due to the incipient development of an internal legislation that was reaching the standards that would allow an effective protection of intellectual property rights, the industrialized countries encouraged the creation of an uniform international standard that would allow its exportation of its creations to enjoy a suitable protection in the destination countries respecting the principles of national treatment and more favoured nation. In that context, the above mentioned countries promoted the subscription of international agreements on the matter, being the most important the Agreement of Paris for the Protection of the Industrial Property of 1883 and the Agreement of Bern for the Protection of the Literary and Artistic Works of $1886^{18}$.

In addition to the above-mentioned agreements, in 1967, the World Organization of the Intellectual property (WIPO), was created, which in 1974 became the organism of United Nations in charge of the protection, and administration of the international system of intellectual property and entrusted to offer extrajudicial disputes solutions in such matter ${ }^{19}$.

Been this the context on the regulation of the protection of intellectual property, it raises the question about ¿what the needs to include intellectual property aspects in international trade agreements are?

\section{1. ¿Why to include intellectual property topics in international trade agreements?}

The inclusion of disciplines on intellectual property in international trade agreements appears with the negotiations of the Uruguay Round in the frame of the World Trade Organization (WTO) that gave birth to the General Agreement on Tariffs and Trade of 1994 (GATT of 1994) and to the Agreement on Aspects of the Rights of Intellectual property Related to Trade (TRIPS Agreement).

More specifically, on September 20, 1986, in the declaration of Punta del Este, Uruguay, the countries parties to the GATT of 1947 agreed to initiate the negotiations of the aspects of the rights of intellectual property related to trade, including trade of goods offenders ${ }^{20}$, that finally in 1994 there gave birth to the TRIPS Agreement, which regulates aspects on copyright, marks, geographical indications, industrial design, patents, varieties of plants scheme of tracing of the integrated circuits and protection of the not spread information.

In accordance with the established in the preamble of the TRIPS Agreement, the member countries of the WTO decide to establish the above-mentioned Agreement with the target to limit the distortions of the international trade and the obstacles to the same one, and for the purpose of encouraging an effective and suitable protection of the rights of intellectual property, and of making sure that the measurements and procedures destined to make to respect the above mentioned rights should not turn into obstacles to the legitimate trade ${ }^{21}$.

The target described to establish the TRIPS Agreement must be understood in the context of the international trade, in a context in which the industrialized countries and its companies were trying to have an important technological and scientific

\footnotetext{
${ }^{18}$ Watch: Pastor Rafael, "The Impact of Free Trade Agreements on Intellectual Property Standards in to Post-TRIPS World" (February, 2006), Pág. 2. in http://www.bilaterals.org/IMG/doc/FTAs and IPS.doc.

${ }^{19} \mathrm{http}: / /$ www.wipo.int/services/es/ (It consults: On May 30, 2016).

${ }^{20}$ Declaration of Punta del Este, Ministerial Declaration of September 20, 1986.

${ }^{21}$ Preamble, TRIPS Agreement.
} 
development in order to conquer the biggest number of markets. In this sense, in full process of globalization and trade liberalization it was turning out to be important to acquire regulations that should protect such creations maintaining a loyal competition between the trading partners.

Considering the existing inequality between the member countries of the GATT with regards to the modernization of its economies and the development of creations that need of the protection of the intellectual property rights, in a beginning it was thought that, these rules were imposed by the developed countries to the developing countries $^{22}$. Nevertheless, although the least developed countries did not need of these protection instruments of an immediate way, it was expected that also they should benefit from these norms in the frame of the WTO.

In the proper TRIPS Agreement, in addition to admitting that the least developed countries needed of flexibility to create a solid and viable technological base, in the article 7 of that agreement it is established that the protection and the observance of the intellectual property rights must contribute to the promotion of the technological innovation and to the transference and diffusion of technology, in reciprocal benefit of the producers and of the users of technological knowledge and so that they favour the social and economic welfare and the balance of rights and obligations ${ }^{23}$.

Although the WIPO existed, this international organization was not the sufficiently effective body for the achievement of its targets; therefore it was turning out to be necessary to constitute another instrument that will allow to give an effective protection of intellectual property rights. In effect, the WIPO has faced some obstacles that have not allowed the organisation to develop its work of an ideal way as for example, the polarization in the decision making (developed country - developing countries) the delay for the review of the Agreement of Paris (and adherence of some agreements or agreements, such as the Lisbon Agreement for the Protection of Appellations of Origin and their International Registration) and the lacking mechanisms for the dispute settlement between the members ${ }^{24}$.

Of the difficulties described in the previous paragraph, the main problem that faces the system of the WIPO it is, undoubtedly, the lack of an effective dispute settlement mechanism that allows solving the controversies arisen on the interpretation and application of its norms, as it happens in case of the WTO in which an institutionalized mechanism exists. Since in the frame of the WIPO only the arbitration and the mediation exists like dispute settlement mechanisms if a country breaches one of its norms, a potential complainant would have to go to the International Court of Justice to demand a rule that should allow the observance of the obligations in the frame of the WIPO, with all the difficulties that it implies ${ }^{25}$.

On the other hand, the dispute settlement mechanism of the WTO, has demonstrated being very effective due to the flexibility that offers to the members, for in any moment

\footnotetext{
${ }^{22}$ SERCOVICH F.C. "Free Trade Agreements, rights of intellectual property and breach of development: politics dimensions from a Latin-American perspective" CEPAL, Mexico D. F., (June, 2008), Pag. 33. (Author translation, original in Spanish).

${ }_{23}$ Article 7, TRIPS Agreement.

${ }^{24}$ ABARZA Jacqueline and KATZ Jorge "The intellectual property rights in the WTO" CEPAL Santiago de Chile, January, 2002. Pág.13. (Author translation, original in Spanish).

${ }^{25}$ For example the article 28 - Differences of the Agreement of Paris for the Protection of the Industrial Property indicates:

1) All difference between two or more countries of the Union, with regard to the interpretation or the application of the present Agreement that has not managed to resolve itself for negotiation route, will be able to be taken by one any of the countries in litigation before the International Court of Justice by means of request done in accordance with the Statute of the Court, unless the countries about litigation are convenient another way of solving it. The International Office claimant will be informed about the difference presented to the Court by the country. The Office will report to other countries of the Union.
} 
during the procedure, to be able to come to a mutually agreed solution. Up to the date in the WTO there have begun 34 cases linked to the obligations established in the TRIPS Agreement ${ }^{26}$, which have been solved mostly at consultation level.

Now, it must be taken into consideration that in accordance to the article 8 of the TRIPS Agreement the countries Members of the WTO preserve the right to adopt measurements as reasons of public health and the nutrition of the population, or to promote the public interest in sectors of vital importance for its socioeconomic and technological development, and to prevent the abuse of intellectual property rights, as long as such measurements are compatible with the TRIPS Agreement ${ }^{27}$.

Additionally, although in the frame of the WTO has not been emphasized the importance of guaranteeing the intellectual property rights to encourage the direct foreign investment, it is clear that a strict and effective legislation on the matter brings more attractiveness to the receiving investment country, given that it is guaranteed to any of them that the above mentioned foreign investments will compete in a loyal way and that they will be able to develop the necessary technological and scientific advances, enjoying full protection for such performance.

Since the culmination of the Uruguay Round, free trade agreements contemplate disciplines on the subject of intellectual property that in some cases replicate the obligations contained in the TRIPS Agreement, while in others, develop disciplines that go beyond the disciplines stablished in the frame of the WTO (so called TRIPS plus).

The proliferation of free trade agreements takes place for the purpose of extending the margins of liberalization of goods and services, deepening the agreements adopted in the WTO, and in the particular case of the aspects of intellectual property related to trade, for the purpose of raising the standards established in the TRIPS Agreement and being able to specify the targets that in the multilateral sphere of the WIPO have not managed to be obtained completely. On this matter, it must be taken into consideration that the national regulation of most of the member countries of the WTO has not been developed in a unilateral way but rather like product of the obligations contracted in the context of the public international law in the frame of the WIPO and the TRIPS Agreement. In this sense, the influence of the development of the regulation on the matter in the international environment is crucial for the development of the national regulation of these countries.

Nevertheless what we express, the bilateral or plurilateral free trade agreements, they do not guarantee a standardized development of the regulation on the subject of intellectual property; the above mentioned agreements allow develop "à la carte" regulation of the established in the TRIPS Agreement and to other topics related to the intellectual property. For some countries, it will be more important, for example, to develop aspects on patents or geographical indications, while they will leave aside, for example, aspects on traditional knowledge, biodiversity or food security, since these topics do not mean for them a systemic and economic interest.

In this sense, although the TRIPS Agreement establishes a base of minimal standards, the development of those mentioned standards in international trade agreements depends on the interests of the negotiator parties. In every negotiation it would be necessary to agree to the aspects of intellectual property related to trade that better fits to the realities of both parties.

\footnotetext{
${ }^{26} \mathrm{https}: / /$ www.wto.org/spanish/tratop_s/dispu_s/dispu_agreements_index_s.htm?id=A26.

${ }^{27}$ Article 8 TRIPS Agreement.
} 
Also, in international trade agreements the parties stablish dispositions on aspects that in the multilateral system of trade have been difficult to agree, for the sensitive topics that are related to these factors, or that are still in negotiation in accordance with the Doha mandate (Declaration of the Fourth Ministerial Conference of the WTO, celebrated in Doha, Qatar, in November, 2001, on the mandate for the negotiations of major disciplines in the WTO).

Some of these sensitive topics on the TRIPS Agreement are for example, its relation with the Agreement on the Biological Diversity, the protection of the traditional knowledge, and to public health topics, as it is the promotion and access to the medicines as well as the research and development of new medicines.

\subsection{Interests of the United States of America and the European Union on the subject of intellectual property in international trade agreements}

In the multilateral context of trade, at the level of the WTO, as well as at the bilateral or plurilateral level, the inclusion of disciplines on intellectual property in free trade agreements has been impelled by a group of countries holders of an important production of goods of big economic value that must be protected legally where the above mentioned goods are used or sold. From the countries or blocks of countries in reference, it is necessary to emphasize the participation of the United States of America and of the European Union ${ }^{28}$, which over the last years have encouraged the regulation development on the intellectual property rights in the international trade agreements that they have signed.

In accordance to the indicated, for the United States Trade Representative (USTR) on its official web page, the above mentioned country and the European Union have the most creative industries of the world, for what it turns out to be indispensable to be provided with a suitable protection of the intellectual property that should encourage the technological innovation, this fact should stimulate the investment in research and development of their economies, and should contribute with the exports and the employment creation to them.

As the USTR recounts, about 40 million works in that country are direct or indirectly related to the intellectual property development ${ }^{29}$. Also, the Department of Trade of that country estimated that the intellectual property generated in 2010,35 per cent of gross national product to them ${ }^{30}$.

For his part, the European Commission has expressed that, in accordance to a study realized by the European Office of Patents and the Office of Harmonization of the Domestic Market (OAMI, at present EUIPO), intellectual property approximately generates 56 million jobs straight from the heavy industries with big development of rights of intellectual property. Also, almost in the same level, in comparison with the United States of America, the intellectual property rights in the European Union represent approximately 39 per cent of the gross national product of the above mentioned block $^{31}$.

In addition to the benefits earlier mentioned, it turns out to be important also to emphasize the losses that could generated not to have a proper regulation on the

\footnotetext{
${ }^{28}$ PASTOR Rafael, "The Impact of Free Trade Agreements on Intellectual Property Standards in to Post-TRIPS World" (February, 2006), Pag. 1. in http://www.bilaterals.org/IMG/doc/FTAs and IPS.doc.

${ }_{29}$ Watch: https://ustr.gov/trade-agreements/free-trade-agreements/transatlantic-trade-and-investment-partnership-t-tip/ttip-10 (Consulted on May 30, 2016).

${ }^{30}$ LATTUS Gene. "The Importance of Intellectual Property Protection to the U.S. Economy", Washington, September 3, 2015, P. 1.

${ }^{31}$ Watch: http://europa.eu/rapid/press-release_IP-13-889_es.htm (consulted on January 2, 2016).
} 
subject of intellectual property, in order to clarify the motivation of strengthening the regulative frame and the observance of this matter in international trade agreements. In accordance with the indicated for the Organization for the Cooperation and the Development Economic (OCDE) in a study develop in 2009, the total in losses of the products falsified and pirated in the international trade in that year might have reached about 250 million American dollars ${ }^{32}$.

In general terms or macro, the development and protection of the intellectual property for the United States of America and the European Union is of supreme importance, given the contribution that this industry has for its economies. In this sense, it turns out to be logical that they impel the development of more strict measures to protect the intellectual property rights in international trade agreements; nevertheless, each of them has different approaches, as it will be analysed further on, due to particularities that will mention latter:

Although the United States of America and the European Union are provided with an intensive industry in intellectual property, in its economies there are some industries that delimit the interest that these have to develop some disciplines on intellectual property predominantly than others. In case of the North American country, the main industries that generate major income and need major protection of intellectual property rights in other countries, to which its products or services are exported, are grouped into 75 industries of 313, in which there stand out those producers of computer and communication, chemists, electrical, pharmaceutical and biotechnological equipment, as well as producers of medical equipment ${ }^{33}$.

For its part, the European Union has presented numbers that show that of 449 industries in the economy of the block it was possible to have determined that 140 are intensive in intellectual property, where the most important are related to the manufacture of motorized hand tools, pharmaceutical products and chemicals products, wines and dairy products, biotechnological and optical products, as well as photographic products and lease of the intellectual property ${ }^{34}$.

As it is appreciated, in both cases there exist similar industries that are considered to be more intensive in intellectual property, such as the production of pharmaceutical and biotechnological products. Nevertheless, we want to highlight that an important difference constitutes the development of the geographical indications that is predominantly important in the European Union, such as: Champagne, Irish and Scotch whisky, prosciutto di Parma, Szegedisalami and the beers Bayerisches Bier and Cesképivo.

In effect, the geographical indications, which are signs used to identify products that have a concrete geographical origin and whose qualities, reputation or characteristics owe essentially to its origin place ${ }^{35}$, they are used principally by the member countries of the European Union in the agricultural sectors, of food and drinks with alcoholic content. By 2010, there were 2768 geographical indications in the European Union mostly associated with wines, spirits and agricultural products ${ }^{36}$.

\footnotetext{
${ }^{32}$ OECD "Magnitude of counterfeiting and piracy of tangible products: an update", Paris, November 2009, p. 3.

${ }^{33}$ Economics and Statistics Administration and United States Patent and Trademark office, "Intellectual Property and The U.S. Economy: Manage in Focus", U.S. Department of Commerce, March 2012.

${ }^{34}$ European Patent Office and the Office for Harmonization in the Internal Market, "Intellectual property rights intensive manage: contribution to economic performance and employment in the European Union: Industry-Level Analysis Report", September 2013.

${ }_{36}^{35}$ http://www.wipo.int/about-ip/es/index.html\#ip (It consults: On May 30, 2016).

$36 \frac{\text { Idem. }}{\text { Idem }}$
} 
This being the scenario, it is possible to appreciate the distinction in content and in form how both the United States and the European Union negotiate and express their concerns on intellectual property in free trade agreements that have been signed with trade partners.

By having a diverse intensive industry in intellectual property, the North American country seeks, in general, develop in free trade agreements all disciplines or categories covering or relating to intellectual property rights such as patents, trademarks, industrial design, internet domain names, ("copyright") and geographical indications ${ }^{37}$. With a systemic vision aimed at strengthening and develop high standards in the protection of intellectual property rights in the international arena, that country establishes in free trade agreements obligations that exceed those obligations established under the TRIPS Agreement and other agreements on intellectual property $^{38}$.

In specific terms, that country emphasizes negotiations in disciplines related to patents, which can be explained by its main intensive industries on intellectual property use to a greater extent this instrument (patents) for the protection of their inventions, being one of its most important sectors the pharmaceutical. Similarly, obligations relating to the enforcement of compliance with the obligations on intellectual property are of utmost importance for this country in the negotiations of trade agreements, because countries with which endorses such agreements face problems of piracy and counterfeit products.

Instead, the objective of the European Union to include provisions on intellectual property in free trade agreements, not due strictly to a systemic interest in strengthening the international system of protection of intellectual property, but rather, and as the Intellectual Property European Commission has indicated, its interest is that artists, inventors, businesses, farmers and European publishers have the possibility of exercise intellectual property rights, allocated to them in third countries, as if they will be within the European Union ${ }^{39}$. In this regard, the priority of the block in the agreements that has signed with its trading partners is to establish a standard that results similar to its legislation on the subject with which he departs from the approach that has the United States of America.

As noted above, the European Union emphasizes the negotiation of obligations regarding intellectual property with respect to geographical indications. Furthermore to the establishment of specific obligations on the matter, incorporates on the intellectual property chapters specific agreements on products such as wine, that employs geographical indications significantly as a protection mechanism.

Thus, the priorities of the United States of America and the European Union have been reflected in free trade agreements that have been signed, giving little room to their counterparts in order to include obligations in the fields of intellectual property which they are not of its interest, as is the case of traditional knowledge and genetic resources, among others.

\footnotetext{
${ }^{37}$ It is necessary to point out that in the United States of America the protection is granted by certification marks or collective marks.

${ }^{38}$ ROFFE, Pedro. "The intellectual property rights in free trade agreements celebrated in Latin America with developed country", CEPAL, Santiago de Chile, April, 2006, p. 5. (Author translation, original in Spanish).

${ }^{39}$ European Commission, "Protection of Intellectual Property in Free Trade Agreements", Brussels, October 2012.
} 


\subsection{Intellectual property in the Andean Community}

Given that Peru and Colombia, belongs to the Pacific Alliance and also are members of the Andean Community (CAN, for initials in Spanish) ${ }^{40}$, it is pertinent to briefly discuss the intellectual property regime under this supranational international organization. The purpose that we pursue with it is to identify the characteristics of this regime and the main aspects that regulate intellectual property, taking into consideration that the legislation of the CAN, in accordance with the Charter of the CAN (the Cartagena Agreement) has prevalence in the territory of its members on any national or international standard (principle of pre-eminence).

The CAN legislation on intellectual property is composed of a common regime on industrial property ${ }^{41}$, common rules on copyright and related rights ${ }^{42}$, a system of protection of the rights of plant breeders ${ }^{43}$ and a common regime on access to genetic resources ${ }^{44}$.

Overall, the industrial property regime establishes for trademark registration and granting patent protection an expeditious and transparent system ${ }^{45}$, in order to achieve greater benefit from scientific and technological advances, as well as promote research. This regime is an adaptation of the CAN legislation to the TRIPS Agreement, which is reflected in the granting of protection of 20 years for patents, the incorporation of the principle of national treatment without restricting it only to members of the CAN, but also for members of the WTO and the Paris Convention, replicating reservations on the matter that are stablish in the TRIPS Agreement and in that Convention ${ }^{46}$. It also removes the prohibition that existed to protect by patent essential items contained in a list published by the World Health Organization, and the restriction that had the CAN members to sign other bilateral or multilateral international agreements on intellectual property $^{47}$.

With regard to the protection of copyright and related rights, given the CAN member countries used to grant different levels of protection at the beginning of the 90s arises the need to harmonize that regime. In this regard, in the late 1993 came into force the Common Regime on Copyright and Related Rights, which was made possible by member countries of the Andean Community, at that time, had ratified the Universal Convention on Copyright, as well as the Berne Convention ${ }^{48}$. This common system dealt with a lot of ambition issues that were later incorporated into the TRIPS Agreement and established a protection period that extends 50 years after the author's death.

Furthermore, within the framework of the CAN also offer protection to breeders of new plant varieties. Plant breeders that have obtained a new plant variety have the exclusive right to produce and commercialization of that plant for a period of 15 to 20 years, except in the case of vines, forest trees or fruit trees, including their rootstocks

\footnotetext{
${ }^{40}$ Bolivia and Ecuador also are members of the CAN.

${ }^{41}$ Decision 486, in force since December 1, 2000, contemplates dispositions on marks, patents, trade names, distinctive signs, industrial secrets and denominations of origin, between others.

42 Decision 351, in force since December 17, 1993.

43 Decision 345 in force since October 21, 1993.

44 Decision 391in force since July 2, 1996.

${ }^{45}$ Watch: http://www.comunidadandina.org/Seccion.aspx?id=83\&tipo=TE\&title=propiedad-intelectual

${ }^{46}$ Andean Centre of Integration, "The Intellectual Property of the Andean Community", p. 1. (Author translation, original in Spanish). In http://centroandinodeintegracion.org/2011/06/02/la-propiedad-intelectual-en-la-comunidad-andina/ (consulted on May 30, 2016).

${ }^{47}$ MAMANI, Wilson, "Changes of politics on the subject of intellectual property in the Andean Community, and its impact in the process of sub regional integration" University Simón Bolivar, Ecuador, 2009, p. 68. (Author translation, original in Spanish).

${ }^{48}$ CERDA, Alberto, "Harmonization of the copyright in the Andean Community: towards a new common regimen" magazine lus ET Praxis, year 17, $\mathrm{N}^{\circ}$ 2, 2011, Santiago de Chile, p. 6. (Author translation, original in Spanish).
} 
that have a protection of 20 to 25 years $^{49}$. This regime is based on the provisions of the Convention of the International Union for the Protection of New Varieties of Plants (UPOV) 1991; however, it departs in some respects as to the scope of protection by excluding discoveries that are covered by UPOV or to include the exception on products grown by the farmer, which is not regulated in the aforementioned international agreement ${ }^{50}$.

With respect to genetic resources and protection of traditional knowledge, CAN has issued 7 Decisions $^{51}$ among which stands out for its content, the Decision 391, Common Regime on Access to Genetic Resources. This standard includes provisions by which the rights and the right of indigenous peoples are recognized to take decisions on their traditional knowledge related to genetic products; also it regulates the procedure for access to genetic products (through access agreements) and promotes a fair and equitable sharing of benefits ${ }^{52}$. In addition to that Decision, it should be noted that in the CAN regime on industrial property (Decision 486) also contains provisions on biological resources and traditional knowledge related to patent registration ${ }^{53}$.

As seen in most cases, the CAN legislation on intellectual property has been adjusted to international agreements on the subject at the multilateral level and there is even a supranational court, called the Court of Justice of the Andean Community, which emits judgments that are preliminary interpretations for intellectual property procedures in the territory of the member countries, been the issue of intellectual property the one that currently generates a significant workload of that Court. In that sense, coexistence between CAN legislation and such multilateral agreements have not been very controversial and, on the other hand, has allowed member countries of the CAN provide an adequate level of protection that benefit trade and the attraction of investors. Nevertheless, the CAN framework puts emphasis on the protection of biodiversity and traditional knowledge, which does not necessarily occur at the multilateral level.

Now, with the signing of free trade agreements with the United States and the European Union, both Peru and Colombia have raised their standards on protection of intellectual property, since these agreements has deepened its regulation establishing obligations and legal figures that had not been included in multilateral agreements such as the TRIPS Agreement or the Paris Convention. This forced these countries to undertake legislative reforms, which they departed from the provisions established in the framework of the CAN.

Trade agreements signed by Peru and Colombia with the United States of America, for example, require parties to sign and ratify international agreements on intellectual property, such as the Convention on Distribution of Program-carrying Signals

\footnotetext{
${ }^{49}$ Watch: http://www.comunidadandina.org/Seccion.aspx?id=83\&tipo=TE\&title=propiedad-intelectual (consulted on May 30, 2015).

${ }^{50}$ Chapter V: Of the Obligations and Rights of the breeder. -

(...)

26. It does not injure the right of holder who reserves and sows for its own use, or blindfold as raw material or food they obtained product of the cultivation of the variety protégée (...).

${ }^{51}$ Decisions 182, 345, 391, 435, 523, 596 and 674.

${ }^{52}$ MAMANI, Wilson, "Changes of politics on the subject of intellectual property in the Andean Community, and its impact in the process of sub regional integration" University Simón Bolívar, Ecuador, 2009, p. 82. (Author translation, original in Spanish).

${ }_{53}$ RUIZ, Manuel, "Analysis of the Decision 486 of the CAN: its legality and applicability as for its requirements on the legal origin of the genetic resources and indigenous traditional knowledge" Program of international matters and biodiversity of the Peruvian society of environmental right, Lima, August, 2002, p. 25. (Author translation, original in Spanish).
} 
Transmitted by Satellite and the Budapest Treaty ${ }^{54}$, which contain provisions that have not been considered in the CAN legislation on intellectual property.

The above-mentioned trade agreements signed with the United States of America establish the possibility of compensate the petitioner of the record of a patent for unreasonable administrative debts in the step to grant the above mentioned record. It also establishes dispositions for the protection of test data in the steps for the approval of a pharmaceutical product and agrochemicals ${ }^{55}$. The bilateral trade agreements not only focus on raising the standard of patent protection, but also regarding matters as copyright and especially on enforcement of protection of intellectual property rights.

This difference between what has been agreed within the CAN and what has been agreed at the bilateral level, specifically with the North American country, generated that Peru impulse the reform of the common intellectual property regime in the CAN. Initially, the proposal was opposed by Bolivia arguing that Peru had infringed the CAN legislation, specifically the Decision 598 which states that "any negotiation of bilateral trade agreements must first preserve the Andean legal system"56.

However, finally the CAN Commission in April 2006 issued the Decision 632 by which authorized its members to protect the test data of pharmaceuticals and agrochemicals. Also in August 2008 it adopted the Decision 689 that allows member countries to development and deepening of the industrial property rights, but through the internal legislation of the members ${ }^{57}$. These modifications allowed both Peru and Colombia could implement the obligations that these countries assumed in its trade agreements with the United States of America, in harmony with the CAN legislation.

We note that the legislation on intellectual property in the CAN maintains the levels of protection of the multilateral agreements on the subject, such as the TRIPS Agreement, the Paris Convention, the Berne Convention, UPOV, among others. However, there has not been able to achieve the standards set out in trade agreements that Peru and Colombia have signed with the United States. The CAN has left to the discretion of its members to raise the standards of protection of intellectual property in their national legislation, thereby cracking the objective of maintaining a common system to regulate this matter at the CAN.

Worth mentioning that, the CAN legislation on intellectual property has been formed by the progress that has been presented at the multilateral level, driven by exporters intellectual property countries and not necessarily by an interest of the CAN members to raise those standards, except for standards concerning to the access of genetic resources linked to the protection of traditional knowledge that from our perspective represent a concern that Peru and Colombia have on the matter, and as we will explain below also share Mexico and Chile.

\footnotetext{
${ }^{54}$ QUEVEDO, Jorge. "Compared analysis: treatment of the intellectual property in the Andean countries", February 2004, p. 45. (Author translation, original in Spanish).

${ }_{55}$ ROFFE, Pedro. "The intellectual property rights in free trade agreements celebrated in Latin America with developed country", CEPAL, Santiago de Chile, April, 2006, p. 19. (Author translation, original in Spanish).

${ }^{56}$ International Centre for Trade and Development, "Peru approves laws of intellectual property opposite to Andean regulation" bridges, volume $9, N^{\circ}$ on July $3,27,2008$, p. 2. (Author translation, original in Spanish).

${ }^{57}$ MAMANI, Wilson, "Changes of politics on the subject of intellectual property in the Andean Community, and its impact in the process of sub regional integration" University Simón Bolívar, Ecuador, 2009, p. 116. (Author translation, original in Spanish).
} 


\subsection{Intellectual property in free trade agreements of the countries of the Pacific Alliance}

The member countries of the Pacific Alliance have had a significant trade liberalization through the signing and implementation of free trade agreements. Thus, Chile ${ }^{58}$ has 25 agreements in force; Colombia ${ }^{59} 11$; Mexico ${ }^{60} 20$ and Peru ${ }^{61} 16^{62}$. In these agreements has prioritized the granting of preferences for trade in goods and services as well as the establishment of investment provisions.

Of the 25 agreements that Chile has, only 11 of them have included provisions on intellectual property; in the case of Colombia, only 6, while in the case of Mexico and Peru, it is contemplated in 10 and 9 respectively. In some cases they have developed separate chapters dealing with various categories that are part of the intellectual property rights, while in others, only included an article in which the rights and obligations assumed in the TRIPS Agreement are reaffirmed or they included specific provisions on a single subject, such as geographical indications.

The four member countries of the Pacific Alliance have signed trade agreements with the United States and the European Union in which they have incorporated chapters on intellectual property; also it can highlight the agreements that these countries have with the European Free Trade Association (EFTA) and Japan ${ }^{63}$. Undoubtedly, these are agreements where this matter has been developed further in relation to other agreements signed by these countries.

As noted above, these agreements are included disciplines on trademarks, geographical indications, copyright and related rights, patents, industrial design, enforcement, public health measures and other issues that were not addressed in the TRIPS Agreement, such as, domain names, test data protection of pharmaceuticals and agrochemicals products and protection of program-carrying signals transmitted by satellite.

While following the implementation of these agreements Chile, Colombia, Mexico and Peru have made changes to its regulations in order to achieve and guarantee the required standards in those agreements for the protection of intellectual property rights, it has not been his priority require other trading partners to also reach those standards. Even in some of the trade agreements between these countries they have not included provisions on intellectual property; such as for example, in the agreement between Chile - Colombia and Chile - Peru.

However, it is appreciate that Chile despite not having included comprehensive provisions covering different aspects of intellectual property in most of its agreements, it included in some of them, specific provisions on geographical indications, which address their specific concerns to protect its spirits. For example, it has done that in the agreements it has signed with Canada, Panama and Vietnam.

Furthermore, it should be borne in mind that three of the four members of the Pacific Alliance, Chile, Mexico and Peru, on February 4, 2016 signed the Trans-Pacific

\footnotetext{
${ }^{58}$ Watch: http://www.direcon.gob.cl/acuerdos-comerciales/ (Consulted on December 10, 2015).

${ }^{59}$ Watch: http://www.tlc.gov.co/publicaciones.php?id=5398 (Consulted on December 12, 2015).

${ }^{60}$ Watch: http://www.gob.mx/se/acciones-y-programas/comercio-exterior-paises-con-tratados-y-acuerdos-firmados-conmexico (Consulted on December 13, 2015).

${ }^{61}$ Watch: http://www.acuerdoscomerciales.gob.pe/ (Consulted on December 9, 2015).

62 It was not considered for any of these countries neither the Agreement by which the WTO is established, nor the Agreement of Cartagena.

${ }^{63}$ ROFFE, Pedro, "Latin America and the intellectual property in the free-trade agreements", on December 19, 2013, p.

1. (Author translation, original in Spanish).
} 
Partnership Agreement (TPP), the one contains without doubt one of the most ambitious chapters on intellectual property rights. The negotiation of this chapter in the TPP could be an element that influenced the decision of the countries of the Pacific Alliance not to include provisions on intellectual property in the Additional Protocol to the Framework Agreement of the Pacific Alliance which came into force on May 1, 2016.

In the TPP Chile, Mexico and Peru have assumed obligations on patents, trademarks, copyrights, industrial designs, geographical indications, trade secrets, as well as provisions on the protection of biodiversity and traditional knowledge.

While most of these obligations have been covered by previous international trade agreements, the TPP have established provisions that some of these countries have not been implemented until this days, such as those provisions limiting the liability of Internet services providers. Also, the TPP includes obligations that for its connection with public health have been difficult to assume. With regard to patents for example, provisions on the protection of test data for pharmaceutical products containing biological components were recorded.

In this context the TPP poses to these countries an advantage, as these has assumed higher standards for the protection of intellectual property, and a challenge to the extent that they should implement certain obligations that have been difficult to bear. Also, given the participation of these countries in the Pacific Alliance also represents an opportunity to ensure that this forum will serve as a space of cooperation for the implementation of the obligations of the TPP on the protection of intellectual property.

Now, within the framework of the Pacific Alliance, as discussed in section III of this paper, has not negotiated a chapter on intellectual property, only it has formed a working group on the matter, as is clear from the Joint Statement of Presidents of the Pacific Alliance ${ }^{64}$, signed on May 23, 2013 in Cali, Colombia. In that sense, the Pacific Alliance provides an opportunity to change the scheme that have usually imposed United States of America and the European Union, among others, to develop disposition on Intellectual Property and, therefore, establish provisions to cover their interest on the matter and had not been included in those agreements.

${ }^{64}$ Watch: https://alianzapacifico.net/temas-de-trabajo/ (Consulted on May 30, 2016). 


\section{PROBLEMS THAT THE COUNTRIES OF THE PACIFIC ALLIANCE FACE TO PROTECT INTELLECTUAL PROPERTY}

In the previous chapter, we appreciated the presence of the subject of intellectual property in the framework of bilateral and multilateral agreements that countries of the Pacific Alliance have supported and signed with various countries and economic blocs, being important and sensitive matter in all these agreements. Now we proceed to detail some examples that motivate that intellectual property is important and sensitive matter in their own territories, what motivates common efforts to shorten distances that allow better integration agenda as bloc in the global economy.

\subsection{Some statistics}

We consider convenient to clarify previously the situation of each country of the Pacific Alliance concerning competitiveness and protection of intellectual property, including the establishment of measures to eradicate counterfeiting and piracy.

Indeed, the 2015-2016 Global Competitiveness Report (GCR), shows the countries of the Pacific Alliance and countries interested in joining this bloc such as Panama and Costa Rica, within the group of the top ten of the region, with high levels of competitiveness, as shown in the following table:

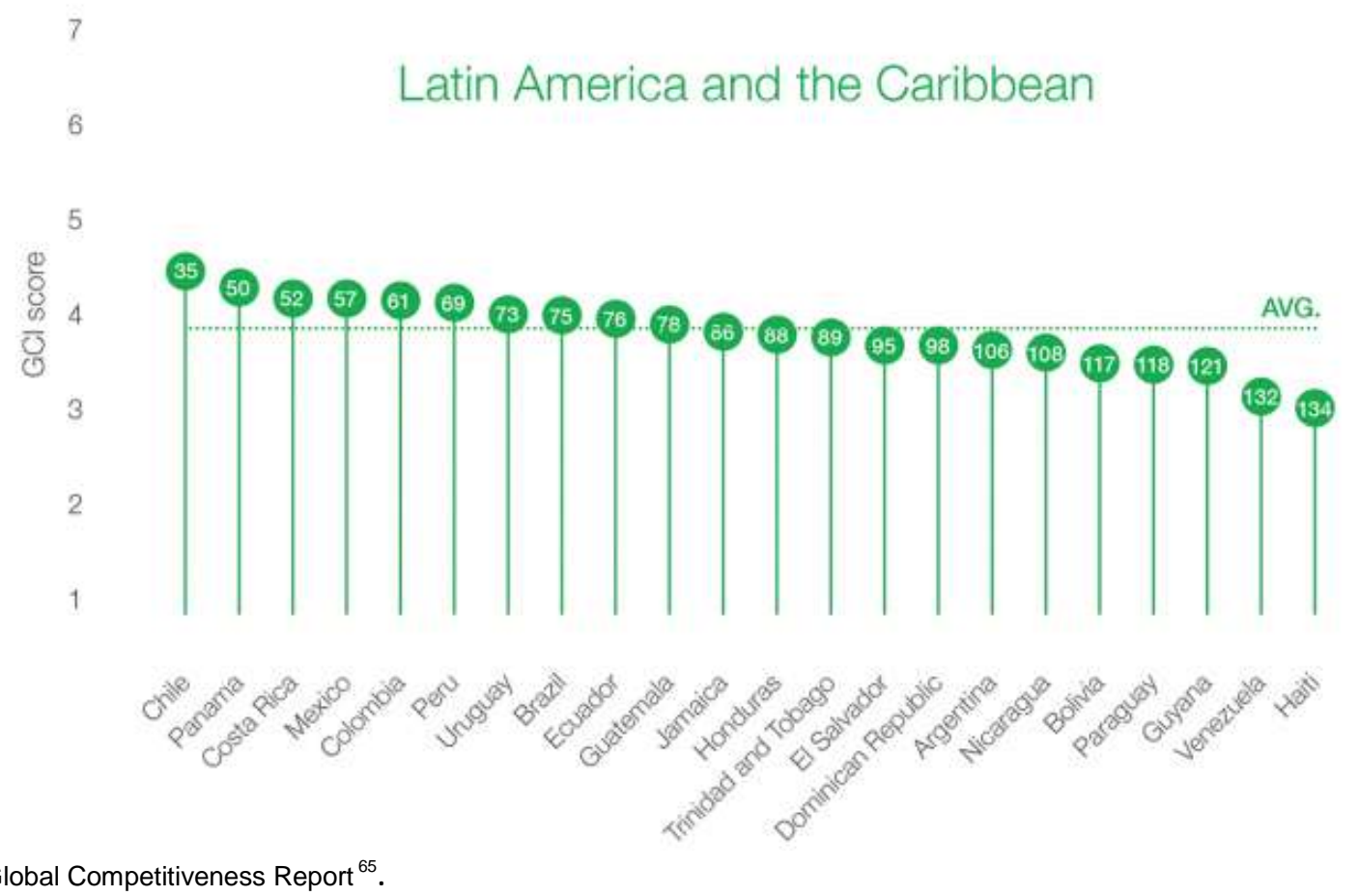

If we consider as reference the year 2011, in which Lima Declaration was submitted to take place later to the formation of the bloc in 2012 in Cerro Paranal (Chile), we may see the evolution of the position of the countries of the bloc with respect to the protection of intellectual property (including the measures taken to combat

\footnotetext{
${ }^{65}$ http://reports.weforum.org/global-competitiveness-report-2015-2016/report-highlights/ (it consults: On November 22, 2015)
} 
counterfeiting), as well as the corresponding values included in the Global Competitiveness Report, of which 1 is the weakest and 7 the strongest.

\begin{tabular}{|c|c|c|c|c|c|c|c|c|}
\hline & 2011-12 & & 2012-13 & & 2013-14 & & 2014-15 & \\
\hline & Position & Value & Position & Value & Position & Value & Position & Value \\
\hline Chile & 63 & 3.6 & 61 & 3.7 & 60 & 3.8 & 56 & 3.9 \\
\hline Colombia & 86 & 3.2 & 89 & 3.2 & 95 & 3.2 & 96 & 3.2 \\
\hline Mexico & 85 & 3.2 & 77 & 3.5 & 77 & 3.6 & 82 & 3.5 \\
\hline Peru & 122 & 2.5 & 127 & 2.6 & 120 & 2.8 & 119 & 2.8 \\
\hline
\end{tabular}

As we may see it, the situation of the country members, except Peru, has remained in the second third of the countries studied (142 in total), all with slight improvement trends. However, these positions and values are somewhat distant with respect to countries in other regions who also share access to the Pacific Ocean, or that take part in multilateral blocs, except South Korea, which experienced a decline during the second third of year 2014-2015. As for candidates for members of the Pacific Alliance, such as Panama and Costa Rica, we may see a steady and even improved position, which the former is in the first third, and the latter is in position to integrate this group, and keeping an advantage over the country with best position (Chile) and a clear advantage over the other country members.

\begin{tabular}{|c|c|c|c|c|c|c|c|c|}
\hline & 2011-12 & & 2012-13 & & 2013-14 & & 2014-15 & \\
\hline & Position & Value & Position & Value & Position & Value & Position & Value \\
\hline Singapore & 2 & 6.1 & 2 & 6.1 & 2 & 6.1 & 2 & 6.2 \\
\hline Canada & 18 & 5.4 & 17 & 5.4 & 13 & 5.6 & 12 & 5.7 \\
\hline Australia & 19 & 5.3 & 19 & 5.3 & 21 & 5.3 & 17 & 5.5 \\
\hline Japan & 22 & 5.3 & 18 & 5.4 & 11 & 5.7 & 7 & 6.0 \\
\hline E.E.U.U. & 28 & 5.0 & 29 & 5.0 & 25 & 5.2 & 20 & 5.4 \\
\hline Panama & 39 & 4.2 & 38 & 4.6 & 35 & 4.6 & 38 & 4.4 \\
\hline $\begin{array}{l}\text { South } \\
\text { Korea }\end{array}$ & 46 & 4.1 & 40 & 4.3 & 48 & 4.0 & 68 & 3.7 \\
\hline $\begin{array}{l}\text { Costa } \\
\text { Rica }\end{array}$ & 70 & 3.5 & 68 & 3.6 & 59 & 3.8 & 49 & 4.0 \\
\hline
\end{tabular}

Self-made table ${ }^{67}$.

However, these positions and values could not be enough if we refer to a bloc with integrationist projection in the global economy and free movement of production factors, what leaves lot of pending work to generate more competitiveness. Such sensation of "pending work" will be reflected below.

The report 301 of year 2015 of the United States Trade Representative - USTR, clearly reflects the position of each country of the Pacific Alliance, which Chile, apparently the country with best position in the aforementioned indicators, appears in the Priority Watch List along with Algeria, Argentina, China, Ecuador, India, Indonesia, Kuwait,

\footnotetext{
${ }^{66}$ Self-made table based on the information of the Global Report of Competitiveness in the following years: http://www3.weforum.org/docs/WEF_GCR_Report_2011-12.pdf,

http://www3.weforum.org/docs/WEF_GlobalCompetitivenessReport 2012-13.pdf,

http://www3.weforum.org/docs/WEF_GlobalCompetitivenessReport_2013-14.pdf,

http://www3.weforum.org/docs/WEF_GlobalCompetitivenessReport_2014-15.pdf (it consults: On June 13, 2016).

${ }^{67}$ Ibid. self-made table (Review: November 22, 2015).
} 
Pakistan, Thailand, Russia, Ukraine and Venezuela, and has remained in this position since 2007, while Colombia, Mexico and Peru have remained in Watch List along with Barbados, Belarus, Bolivia, Brazil, Bulgaria, Canada, Costa Rica, Dominican Republic, Egypt, Greece, Guatemala, Jamaica, Lebanon, Paraguay, Romania, Tajikistan, Trinidad and Tobago, Turkey, Turkmenistan, Uzbekistan and Vietnam ${ }^{68}$.

Although each country of the Pacific Alliance have some common points that have inspired the formation of the bloc, such as the opening of markets and integration through trade promotion agreements in which intellectual property matters were included, each of them has several point pending to implement and improve, as shown in the following information.

\begin{tabular}{|c|c|}
\hline Chile & Colombia \\
\hline $\begin{array}{l}\text { Concern: long-term implementation of } \\
\text { intellectual property rights under the USA- } \\
\text { Chile Free Trade Agreement. }\end{array}$ & $\begin{array}{l}\text { Concern: implement important } \\
\text { commitments related to intellectual } \\
\text { property rights under the CTPA (Colombia } \\
\text { Trade Promotion Agreement), including } \\
\text { commitments to counter piracy of } \\
\text { copyright in the digital age through mobile } \\
\text { devices. }\end{array}$ \\
\hline Mexico & Peru \\
\hline $\begin{array}{l}\text { Concern: widespread availability of } \\
\text { pirated and counterfeit products in Mexico } \\
\text { and the growing Internet piracy by } \\
\text { increasing broadband penetration. }\end{array}$ & $\begin{array}{l}\text { Concern: widespread availability of } \\
\text { falsified and pirated products in Peru. }\end{array}$ \\
\hline
\end{tabular}

Self-made table and translation

We may see that each country maintains a so-called "bottleneck", what leads to big concerns and actions to reduce and get rid of them, as quoted below:

\footnotetext{
${ }^{68} \mathrm{https}$ //ustr.gov/sites/default/files/2015-Special-301-Report-FINAL.pdf. (Review: November 22, 2015). In reference, of the special report 301 (Special 301 Report) categories List Enforcement Priority Watch List (PWL) and Watch List (WL) to identify the countries with which the United States of America does trade and determine certain problems in the protection and enforcement of intellectual property rights.
} 


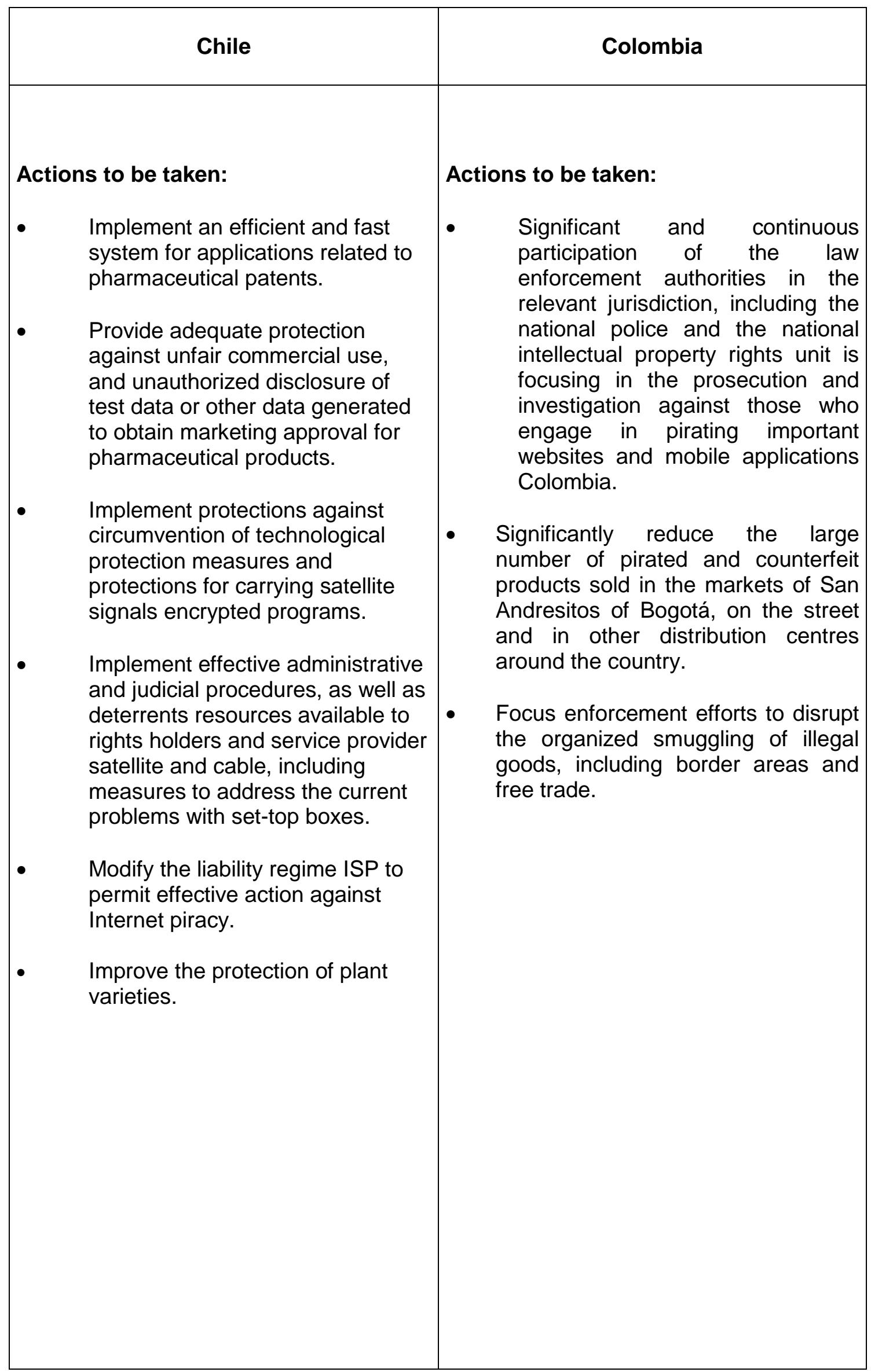




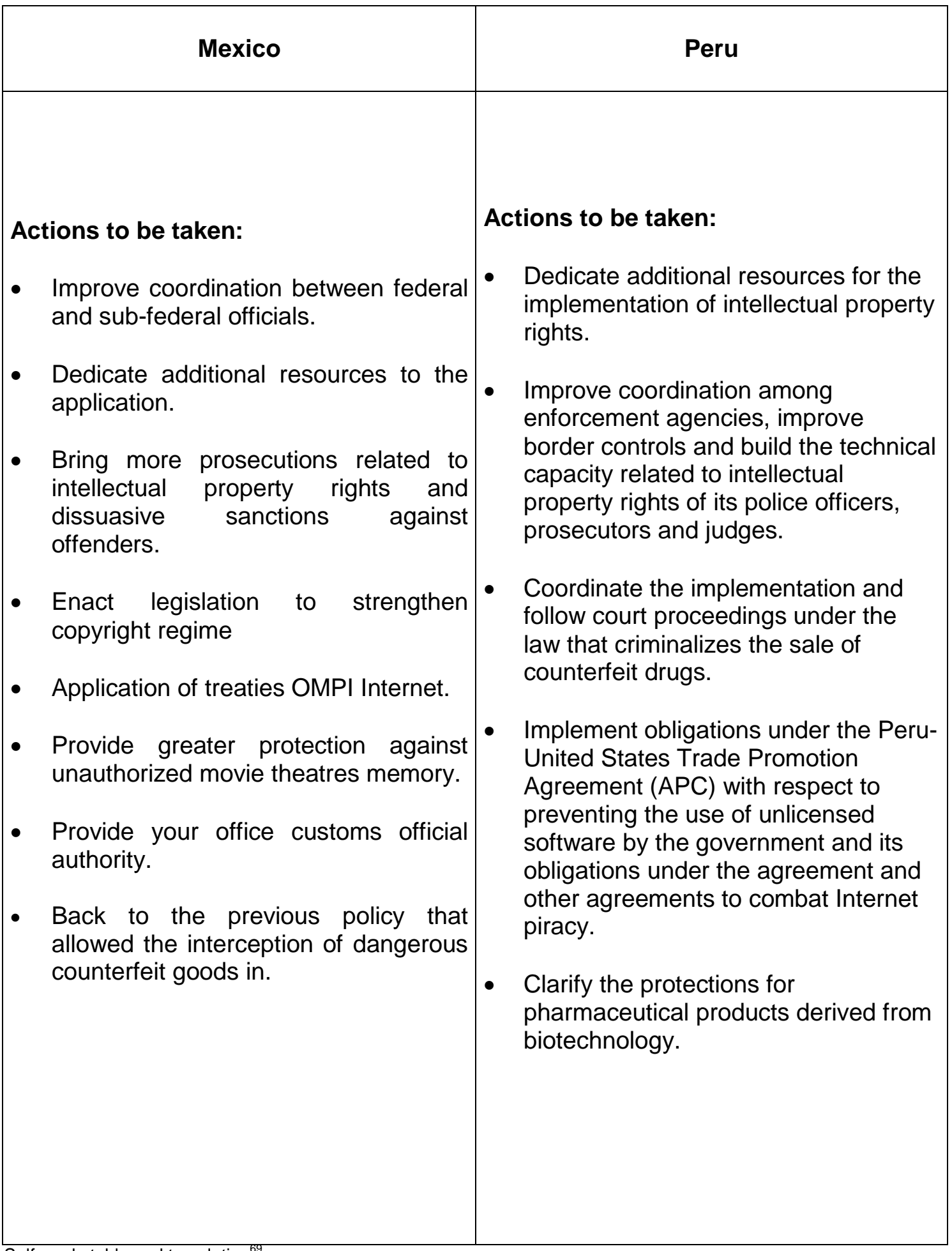

Self-made table and translation ${ }^{69}$.

Finally, in Special Report 301 of 2016, Chile remains in Priority Watch List, while Peru, Colombia y Mexico remain in Watch List. With the signing of the Trans-Pacific Partnership (TPP), there is a need to implement it by Chile, Mexico and Peru, while Colombia is committed to implement the National Development Plan, which became law in June 2015, and contains provisions intended to develop enforcement policy to help coordinate and generate awareness on respect for intellectual property rights ${ }^{70}$.

\footnotetext{
${ }^{69}$ Self-made table and translations

${ }^{70}$ https://ustr.gov/sites/default/files/USTR-2016-Special-301-Report.pdf (Review: June 13, 2016).
} 


\subsection{Piracy and counterfeiting}

The commercialization (both in formal and informal channels) of products containing a registered mark and/or a copyrightable work without authorization of the titleholders is a recurring problem in the countries of Pacific Alliance. Not only are diverse group of interest affected (titleholders, consumers), but also the countries are also affected as they are not able to fulfill standards required on a global scale.

As for the commercialization or distribution channels (fair fields, or "flea market"), some places have become well-known. In Mexico, Tepito has been a motive of wide coverage like one of the most important places for the commercialization of counterfeited products or piracy, going so far as to provide even to international markets where the levels of respect and control of products that can affect the intellectual property rights are higher ${ }^{71}$. Similar situation happens with regard to "San Juan de Dios" Market in Guadalajara ${ }^{72}$ and the reports of International Intellectual Property Association (IIPA) other places such as "Lomas Verdes", "La Fallluca", "Plaza Meave", "Juarez o Central Camionera", "Salto de Agua", "La Cuchilla", "Pulga Río", "Pulga Guadalupe", "Plaza Lido", etc. are also mentioned. ${ }^{73}$

Although there have been some intentions of formalization in Peru, that includes the respect of the rights of intellectual property, the shopping centre named "El Hueco" has always been a referent as for the infringement of the above mentioned rights, being a curious case since their galleries are located close to the head offices of judicial authorities and the Attorney General, in full heart of the city centre of Lima ${ }^{74}$. Other places also are known such as Gallery "Las Palmas", in Chile, or "San Andresitos", in Colombia.

Not only have these places acquired some recognition in piracy terms through the sale of illegal supports but also the problem arises through the digital piracy. According to the report issued by IIPA in 2015, the places h2zone.cl and Neo Games.cl, hosted and operating in Chile, are still the leading providers of technological measures circumvention, of which there are no protection means. In that sense Chile is the ninth country on a global scale in P2P (peer-to-peer) infringements concerning video games based on consoles ${ }^{75}$.

The problems of these cases not only consists of a legal matter, linked with the existence or not of sufficient legislation with more deterrent sanctions, or the existence of authorities sufficiently training to fight the illegal channels of import and commercialization, both at formal and informal level. The problem of the piracy could be explained by the deficit in the presence of suppliers in the market, so that the piracy has turned out to be a substitute in the provision of cultural goods in some places

\footnotetext{
71 The following news and reports be http://www.bbc.com/mundo/noticias/2011/03/110301_pirateria_lugares_paginas_jmp.shtml, http://www.cnnexpansion.com/economia/2014/02/12/tepito-lider-mundial-de-pirateria,

http://www.elfinanciero.com.mx/sociedad/tepito-dentro-de-los-mercados-que-mas-le-pegan-a-eu-por-pirateria.html (Review: June 13, 2016).

72 The following news and reports can be seen in: http://www.jornada.unam.mx/ultimas/2014/02/12/incluye-eu-amercados-de-tepito-y-san-juan-de-dios-en-lista-negra-de-pirateria-6082.html,

http://mexico.cnn.com/nacional/2014/02/13/eu-pone-en-su-lista-negra-a-tepito-y-al-mercado-de-san-juan-de-dios

(Review: June 13, 2016).

${ }^{73} \mathrm{http}: / /$ www.iipa.com/rbc/2015/2015SPEC301MEXICO.pdf (consulted: On June 13, 2016).

74 The following news and reports can be seen in: http://rpp.pe/lima/actualidad/el-hueco-y-polvos-azules-vendenpeliculas-peruanas-originales-desde-s-7-noticia-770021, http://gestion.pe/empresas/centro-comercial-hueco-ya-novendera-discos-piratas-evitar-cierre-2101537, http://larepublica.pe/30-07-2013/el-hueco-un-espacio-que-subsistedesde-hace-21-anos-en-la-informalidad,http://www.andina.com.pe/agencia/noticia-decomisan-centro-comercial-hueco2-millones-videos-piratas-516420.aspx(Review: June 13, 2016).

${ }_{75}$ http://www.iipa.com/rbc/2015/2015SPEC301CHILE.pdf (Review: June 13, 2016).
} 
isolated or far away from the big cities. Besides, the piracy could be also explained as an awareness matter between the population and the authorities; thus, people acquire illegal products and even the sellers are placed in the presence of consumers in spite of the pernicious effects already known by consumers and such authorities ${ }^{76}$.

Finally, given the emergence of new technologies, we can appreciate the following spaces on which this issue must be addressed: a) piracy and counterfeiting in the analog world; b) piracy and counterfeiting promoted in the digital world; c) the impact of new techniques and technologies in reproduction of objects that may be protected under an industrial property right or copyright (for example, the so-called 3D) and possible violations that may occur with those rights.

\subsection{Country Marks}

In recent years we have witnessed the promotion of positive aspects of a country to generate investment and promote tourism, through the use of signs that could be representatives and could generate a great impact in the same country and abroad.

Although there isn't much literature, the issue of country marks, beyond a source that we consider more related to marketing than legal, has generated some interest on the latter to ensure adequate protection for all products or services for which the mark will be used. Below we can find existing trademark registrations in their respective countries.

\begin{tabular}{|c|c|c|c|}
\hline Mark & $\begin{array}{c}\text { Country of } \\
\text { registration }\end{array}$ & Owner & Status \\
\hline & Peru & $\begin{array}{l}\text { Comisión de } \\
\text { Promoción del Perú } \\
\text { para la Exportación y } \\
\text { el Turismo- } \\
\text { PROMPERU }\end{array}$ & $\begin{array}{l}\text { - Certificate: T2566 } \\
\text { (multiclass, to cover all } \\
\text { classes of good and } \\
\text { services, except } \\
\text { pharmaceutical goods) } \\
\text { - Certificate: } 179302 \text { (to } \\
\text { cover pharmaceutical } \\
\text { goods and others in } \\
\text { class } 5 \text { of Nice } \\
\text { Classification) }\end{array}$ \\
\hline & Colombia & $\begin{array}{c}\text { Fiduciaria } \\
\text { Colombiana de } \\
\text { Comercio Exterior } \\
\text { S.A. FIDUCOLDEX } \\
\text { actuando como } \\
\text { vocera del } \\
\text { Fideicomiso de } \\
\text { Promoción de } \\
\text { Exportaciones } \\
\text { PROEXPORT } \\
\text { COLOMBIA }\end{array}$ & $\begin{array}{l}\text { Certificate } N^{\circ} 468474 \\
\text { (collective mark to cover } \\
\text { service in class } 35 \text { of Nice } \\
\text { Classification) }\end{array}$ \\
\hline
\end{tabular}

${ }^{76}$ RAMIREZ, Luis. "Who is the villain of the movie? Piracy as tolerable and access to cultural property" RAE jurisprudence Year 4, took 47, In May 2012, p.273 to 275. (Author translation, original in Spanish). 


\begin{tabular}{|c|c|c|c|}
\hline numa unt & Colombia & $\begin{array}{c}\text { Fiduciaria } \\
\text { Colombiana de } \\
\text { Comercio Exterior } \\
\text { S.A. FIDUCOLDEX } \\
\text { actuando como } \\
\text { vocera del } \\
\text { Fideicomiso de } \\
\text { Promoción de } \\
\text { Exportaciones } \\
\text { PROEXPORT } \\
\text { COLOMBIA }\end{array}$ & $\begin{array}{l}\text { Certificate } N^{\circ} 468477 \\
\text { (collective mark, to cover } \\
\text { services in class } 35 \text { of Nice } \\
\text { Classification ) }\end{array}$ \\
\hline & Colombia & $\begin{array}{c}\text { Fiduciaria } \\
\text { Colombiana de } \\
\text { Comercio Exterior } \\
\text { S.A. FIDUCOLDEX } \\
\text { actuando como } \\
\text { vocera del } \\
\text { Fideicomiso de } \\
\text { Promoción de } \\
\text { Exportaciones } \\
\text { PROEXPORT } \\
\text { COLOMBIA }\end{array}$ & $\begin{array}{l}\text { Certificate } N^{\circ} 468472 \\
\text { (collective mark, to cover } \\
\text { services in class } 41 \text { of Nice } \\
\text { Classification) }\end{array}$ \\
\hline & Colombia & $\begin{array}{c}\text { Fiduciaria } \\
\text { Colombiana de } \\
\text { Comercio Exterior } \\
\text { S.A. FIDUCOLDEX } \\
\text { actuando como } \\
\text { vocera del } \\
\text { Fideicomiso de } \\
\text { Promoción de } \\
\text { Exportaciones } \\
\text { PROEXPORT } \\
\text { COLOMBIA }\end{array}$ & $\begin{array}{l}\text { Certificate } N^{\circ} 468478 \\
\text { (collective mark, to cover } \\
\text { service in class } 41 \text { of Nice } \\
\text { Classification) }\end{array}$ \\
\hline mertesmats & Colombia & $\begin{array}{c}\text { Fiduciaria } \\
\text { Colombiana de } \\
\text { Comercio Exterior } \\
\text { S.A. FIDUCOLDEX } \\
\text { actuando como } \\
\text { vocera del } \\
\text { Fideicomiso de } \\
\text { Promoción de } \\
\text { Exportaciones } \\
\text { PROEXPORT } \\
\text { COLOMBIA }\end{array}$ & $\begin{array}{l}\text { Ongoing international } \\
\text { trademark to cover services } \\
\text { in class } 35 \text { of Nice } \\
\text { Classification (application } \\
\text { 144270) }\end{array}$ \\
\hline & Chile & $\begin{array}{l}\text { Fundación Imagen de } \\
\text { Chile }\end{array}$ & $\begin{array}{l}\text { Service mark applied for } \\
\text { and withdrawn in } 2011\end{array}$ \\
\hline
\end{tabular}




\begin{tabular}{|l|l|l|l|}
\hline & Chile & $\begin{array}{l}\text { Fundación Imagen de } \\
\text { Chile }\end{array}$ & $\begin{array}{l}\text { Certificate No 957614 to } \\
\text { cover services in class } 35 \text { of } \\
\text { Nice Classification }\end{array}$ \\
\hline Mexico & Secretaría de Turismo & $\begin{array}{l}\text { Certificate No604142 to } \\
\text { cover services in class 35 of } \\
\text { Nice Classification, expiring } \\
\text { on November 19, 2008 }\end{array}$ \\
\hline Mexico & Secretaría de Turismo & $\begin{array}{l}\text { Cortificate No698252 to } \\
\text { Nice Classification, expiring } \\
\text { on March 9, 2011 }\end{array}$ \\
\hline
\end{tabular}

This protection should be focused not only on the corresponding registration in the country of origin but must also include international protection, according to the trademark principle of territoriality, and pursuant to the specific requirements of each country or territory in which the mark will be protected. Thus, in the case of the United States of America, the protection will be based on use or intended use, while we will have to determine whether the protection desired is national or Community (CTM) in Europe. Additional cost and fees should be taken into account not only at the initial stage (the registration), but also in subsequent moments such as the renewal, or other substantial costs such as the campaigns to launch a new image through this mark and legal actions to protect the mark against unauthorized use.

Below we can see the following registration of country marks in countries of the Pacific Alliance and other relevant territories.

\begin{tabular}{|c|c|c|c|}
\hline Mark & $\begin{array}{c}\text { Country of } \\
\text { registration }\end{array}$ & Owner & Status \\
\hline Chile & $\begin{array}{c}\text { Comisión de } \\
\text { Promoción del Perú } \\
\text { para la Exportación y } \\
\text { el Turismo- } \\
\text { PROMPERU }\end{array}$ & $\begin{array}{l}\text { Certificate No 1102329 (to } \\
\text { cover clothing, footwear, } \\
\text { headgear, in class 225 of } \\
\text { Nice Classification) }\end{array}$ \\
\hline
\end{tabular}




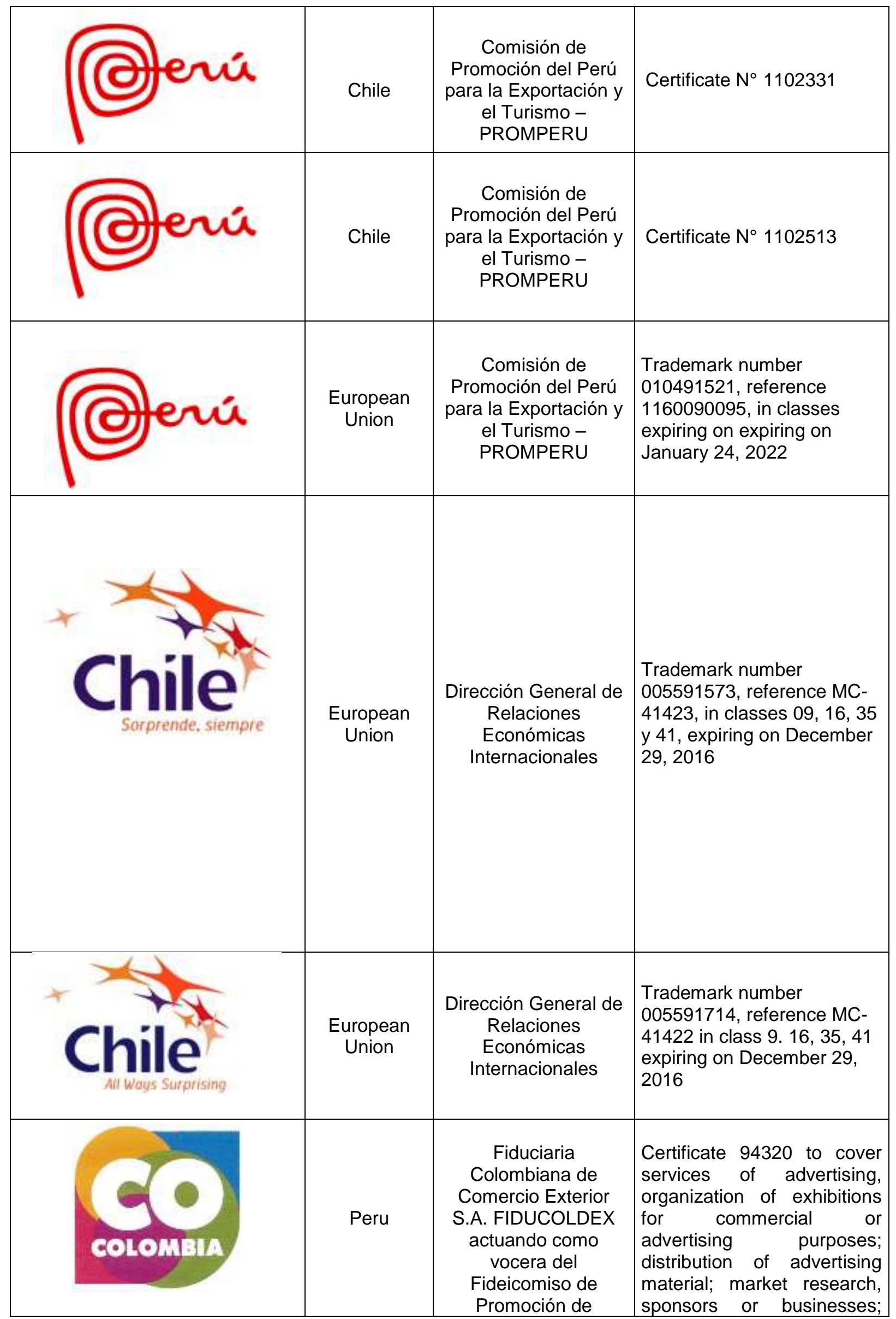




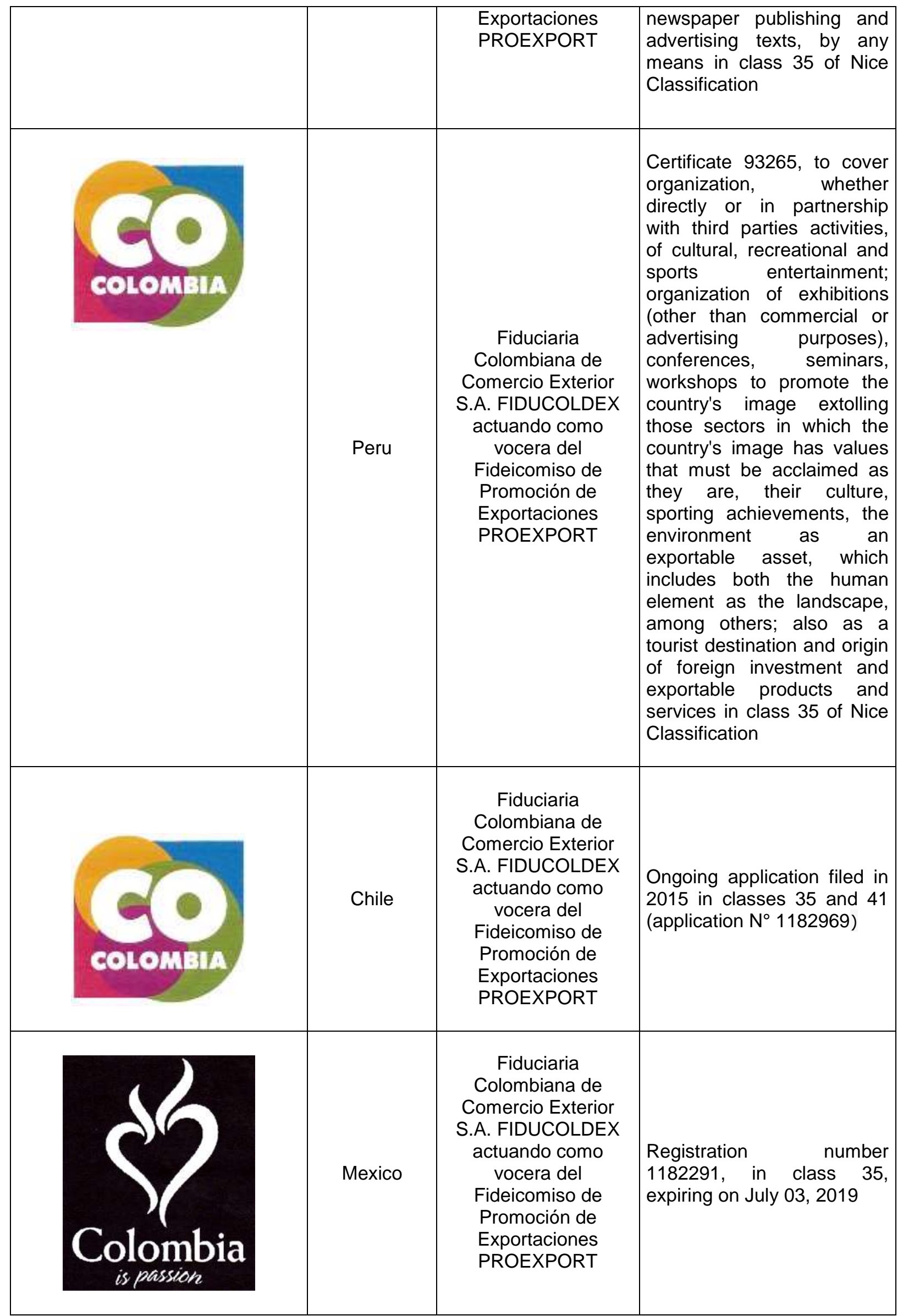




\begin{tabular}{|c|c|c|c|}
\hline$\underset{\text { es pasiön! }}{\text { Colombia }}$ & Mexico & $\begin{array}{c}\text { Fiduciaria } \\
\text { Colombiana de } \\
\text { Comercio Exterior } \\
\text { S.A. FIDUCOLDEX } \\
\text { actuando como } \\
\text { vocera del } \\
\text { Fideicomiso de } \\
\text { Promoción de } \\
\text { Exportaciones } \\
\text { PROEXPORT }\end{array}$ & $\begin{array}{l}\text { Registration number } \\
1017780 \text {, in class } 35 \text {, } \\
\text { expiring on July } 03,2019\end{array}$ \\
\hline & $\begin{array}{l}\text { European } \\
\text { Union }\end{array}$ & $\begin{array}{c}\text { Fiduciaria } \\
\text { Colombiana de } \\
\text { Comercio Exterior } \\
\text { S.A. FIDUCOLDEX } \\
\text { actuando como } \\
\text { vocera del } \\
\text { Fideicomiso de } \\
\text { Promoción de } \\
\text { Exportaciones } \\
\text { PROEXPORT, } \\
\text { SEGMENTO MARCA } \\
\text { PAÍS PROEXPORT } \\
\text { COLOMBIA }\end{array}$ & $\begin{array}{l}\text { Trademark number } \\
1172086 \text {, in class } 35, \\
\text { expiring on June 17, } 2023\end{array}$ \\
\hline & $\begin{array}{l}\text { European } \\
\text { Union }\end{array}$ & $\begin{array}{c}\text { Fiduciaria } \\
\text { Colombiana de } \\
\text { Comercio Exterior } \\
\text { S.A. FIDUCOLDEX } \\
\text { actuando como } \\
\text { vocera del } \\
\text { Fideicomiso de } \\
\text { Promoción de } \\
\text { Exportaciones } \\
\text { PROEXPORT, } \\
\text { SEGMENTO MARCA } \\
\text { PAÍS PROEXPORT } \\
\text { COLOMBIA }\end{array}$ & $\begin{array}{l}\text { Trademark number } \\
1188605 \text {,in class } 41, \\
\text { expiring on June 17, } 2023\end{array}$ \\
\hline & Chile & $\begin{array}{c}\text { Consejo de } \\
\text { Promoción Turística } \\
\text { de México S.A. de } \\
\text { C.V. }\end{array}$ & $\begin{array}{l}\text { Application filed in } 2008 \text { and } \\
\text { rejected in } 2010 \text { (class 16) }\end{array}$ \\
\hline & Chile & $\begin{array}{c}\text { Consejo de } \\
\text { Promoción Turística } \\
\text { de México S.A. de } \\
\text { C.V. }\end{array}$ & $\begin{array}{l}\text { Application filed in } 2008 \text { and } \\
\text { rejected in } 2010 \text { (class 25) }\end{array}$ \\
\hline
\end{tabular}




\begin{tabular}{|c|c|c|c|}
\hline & Chile & $\begin{array}{c}\text { Consejo de } \\
\text { Promoción Turística } \\
\text { de México S.A. de } \\
\text { C.V. }\end{array}$ & $\begin{array}{l}\text { Application filed in } 2008 \text { and } \\
\text { rejected in } 2010 \text { (class 35) }\end{array}$ \\
\hline & Chile & $\begin{array}{c}\text { Consejo de } \\
\text { Promoción Turística } \\
\text { de México S.A. de } \\
\text { C.V. }\end{array}$ & $\begin{array}{l}\text { Application filed in } 2008 \text { and } \\
\text { rejected in } 2010 \text { (class 43) }\end{array}$ \\
\hline & $\begin{array}{l}\text { European } \\
\text { Union }\end{array}$ & $\begin{array}{c}\text { Consejo de } \\
\text { Promoción Turística } \\
\text { de México S.A. de } \\
\text { C.V. }\end{array}$ & $\begin{array}{l}\text { Trademark number } \\
008258782 \text {, reference } 2842 \text {, } \\
\text { classes 25, 35, 43, expiring } \\
\text { on April 29, 2019 }\end{array}$ \\
\hline$E$ & $\begin{array}{l}\text { European } \\
\text { Union }\end{array}$ & $\begin{array}{c}\text { Consejo de } \\
\text { Promoción Turística } \\
\text { de México S.A. de } \\
\text { C.V. }\end{array}$ & $\begin{array}{l}\text { Trademark number } \\
008258857 \text { reference } 2843, \\
\text { class } 16 \text {, expiring on April } \\
29,2019\end{array}$ \\
\hline
\end{tabular}

These lists of country marks are mere illustrative as we have not seen any record of country marks of Mexico or Chile in the website of the Colombian authority (Superintendence of Industry and Commerce), and we have not seen any registration of country mark Chile in the website of the Mexican authority (Mexican Institute Property Industrial- IMPI) either. These facts could reflect a problem in the international protection which could be justified by high costs and professional fees to be incurred in protecting the marks in each country. If the marks are already registered, they must be renewed every ten years, what could be a problem in maintenance if such mark is not being used or the country is using a different image as country mark, and hence a new registration is necessary instead of filing renewal of the already registered mark.

The country mark is not an exclusive issue related to the countries of the Pacific Alliance. However, this bloc could be an opportunity to try a sui generis system to protect this new intangible asset, which is able to generate not a mere association to a specific business origin but an association to a country origin or positive aspects of a certain country. This sui generis protection could be oriented to obtain a fast recognition of this industrial property asset with lower costs.

Several cases have occurred and have brought attention to this issue. Thus, we can mention the case of patent granted over native plant varieties in the region. In the case of quinoa, a patent is United States of America was granted consisting of a variety cultivated in Bolivia (not member of the Pacific Alliance) and then there was a desire to make this patent available to researchers in this country and Chile ${ }^{77}$.

\footnotetext{
${ }_{77}$ CAILLAUX, Jorge. "Access to the genetic resources. In: How to prepare the bio piracy in Peru? Reflections and proposals". Lima, Lerma Gómez EIRL, May, 2005, p. 36 to 38. (Author translation, original in Spanish).
} 
Then, based on the existence of patents in United States of America and an international patent application based on Maca (Lepidium meyenii), steps were made to disseminate this problem internationally and the enactment in Peru Law No. 28216, Law on Protection of access to Peruvian biological diversity and collective knowledge of indigenous people ${ }^{78}$. There were also coordinated actions by the Peruvian authorities and interest groups through the National Commission against Biopiracy to prevent biopiracy, trade restrictions and damages to national interests and native communities $^{79}$. As for the Maca, the following cases have happened:

\begin{tabular}{|l|l|l|l|l|}
\hline \multicolumn{1}{|c|}{ Title } & $\begin{array}{c}\text { Application } \\
\text { number }\end{array}$ & Publication date & \multicolumn{1}{|c|}{ Main claim } & Status \\
\hline $\begin{array}{l}\text { Compositions and } \\
\text { methods from } \\
\text { Lepidium }\end{array}$ & $\begin{array}{l}\text { WO 0051548 } \\
\text { (A2) }\end{array}$ & $\begin{array}{l}\text { September 08, } \\
2000\end{array}$ & $\begin{array}{l}\text { Method for treating } \\
\text { and preventing } \\
\text { sexual dysfunction }\end{array}$ & $\begin{array}{l}\text { Patent } \\
\text { rejected }\end{array}$ \\
\hline $\begin{array}{l}\text { Preparation method } \\
\text { and a composition of } \\
\text { an extract of Maca }\end{array}$ & Kr20070073663 & May 11,2006 & $\begin{array}{l}\text { Maca extract that } \\
\text { improves the fertility } \\
\text { male }\end{array}$ & $\begin{array}{l}\text { Patent } \\
\text { rejected }\end{array}$ \\
\hline $\begin{array}{l}\text { Functional food } \\
\text { containing maca }\end{array}$ & JP 2004-000171 & January 8, 2004 & $\begin{array}{l}\text { Functional food } \\
\text { containing Maca, } \\
\text { characterized by } \\
\text { increasing the level } \\
\text { of growth hormone } \\
\text { in the blood }\end{array}$ & $\begin{array}{l}\text { Patent } \\
\text { rejected }\end{array}$ \\
\hline $\begin{array}{l}\text { Relief for sleep } \\
\text { disorders }\end{array}$ & JP2007031371 & $\begin{array}{l}\text { February 02, } \\
2007\end{array}$ & $\begin{array}{l}\text { Alcoholic extract of } \\
\text { Maca that relieves } \\
\text { the sleep disorders }\end{array}$ & $\begin{array}{l}\text { Patent } \\
\text { application } \\
\text { abandoned }\end{array}$ \\
\hline
\end{tabular}

Self-made table ${ }^{80}$.

The existence of these cases, and others such as green cotton, or the intention to obtain a patent on a yellow bean variety that is cultivated in Mexico ${ }^{81}$, or patent applications on Sacha inchi (Plukenetia Volubilis), wherein there was an action by the National Commission against Bio-Piracy to negotiate, that led the two applicant companies abandon the application for patents. ${ }^{82}$, generate great concern to maintain coordinated actions among country members to facilitate information regarding the native varieties that could be subject matter of patents unduly granted in diverse countries.

\footnotetext{
${ }^{78}$ MORALES, Pedro. "Law 28216 Law of Protection to the access of the Peruvian biological diversity and the collective knowledge of the indigenous peoples". In: Op. Cit., p. 48 and 49. (Author translation, original in Spanish).

${ }^{79}$ To major abundance, see the document "Report Patent referred to the Lepidium meyeni i (bruise): Answers of Peru" en:http://www.indecopi.gob.pe/documents/20182/177609/InforFinalPatLepiMey.pdf (Review: June 13, 2016).

${ }^{80}$ Self-made table based on information in: http://biocan.comunidadandina.org/biocan/images/documentos/Taller\%20ARG\%20indigena/Presentaciones\%201\%20d \%C3\%ADa/Comisi\%C3\%B3n\%20Nacional\%20contra\%20la\%20Biopirater\%C3\%ADa.pdf (Review: June 13, 2016)

${ }_{81}$ VENERO, Begoña. "Myths and truths on the Bio piracy and the Intellectual property". In: Andean yearbook of Intellectual Rights $\mathrm{N}^{\circ} 1$, p. 227. (Author translation, original in Spanish).

${ }^{82}$ FERRO C. Pamela. "Wide-brimmed straw hat. The case of the Sacha Inchi (Plukenetia volubilis I). And the new one in the direction of taking for the National Commission against the Bio piracy". In: Andean yearbook of intellectual Rights $\mathrm{N}^{\circ}$ 6, p. 270. (Author translation, original in Spanish).
} 


\subsection{Trademark protection of designations that identify elements of national and international cuisine}

In recent years there have been efforts from both private and government sectors to spread the elements that are part of the cuisine of each country, in order to promote tourism and generate a sense of identity in a nation.

In gastronomy, it has already been various concerns about the protection through intellectual property. Thus, MARAVI noted that traditional cuisine could not be protected by copyright because it does not meet the requirement of originality. Although it might be considered the gourmet dishes as original, given the combination and selection of ingredients, it would be difficult for the authority to grant any protection. In the case of recipes, they could be original to the extent they are expressed in the form of a poem, song or graphic format and although the holder would oppose any unauthorized reproduction could not keep the dishes described to prepare ${ }^{83}$.

On the other hand, there have been comments on the effects of trademark registrations filed in Chile in recent years that have included the term "Suspiro Limeño". Chilean authorities indicated that term, considered in isolation, could not be protected as a trademark because it identifies an original dessert of Peru, but may be part of trademark registrations to the extent that there are other distinctive elements that may identify a particular business origin. Resolutions of this kind give the possibility of raising a state strategy aimed at protecting the other elements of Peruvian cuisine ${ }^{84}$.

In such comments, the case of registration of SHAHUERMA SHISH KABAB GRILL \& BAR (word) was also mentioned. Such mark was applied for in Peru to distinguish services restaurant, bar and grill in class 43 of Nice Classification. Peruvian Authority indicated that "Shahuerma" referred to food of Arabic origin made from lamb, turkey, veal or grilled chicken, while the term "Shishkabab" (Shish Kebab) referred to food of Arabic origin made from lamb on skewers, so it could not fall any exclusive rights in relation to such services ${ }^{85}$.

In Colombia, trademark registrations, containing elements that identify the national origin of the dish that is sold as part of restaurant services, have been granted, such as CEVICHERIA DEL PERU and logo, in which the Colombian authority has stated explicitly that the term "PERU" is understood as explanatory (Certificate No. 473029), or REAL AREPA and logo, which noted that "THE REAL AREPA VENEZOLANA" was an explanatory phrase (Certificate No. 505658).

Moreover, the Intellectual Property Chamber of the Tribunal of INDECOPI in Peru indicated that it was becoming increasingly common in the market the use of terms in a foreign language to refer to the services of sale of food,. Thus, names such as "ristorante", "cuisine", "trattoria", "pâtisserie", "délicatesse" among others, (which belong to French and Italian), are not likely by themselves to identify a commercial origin, so that they could be used and/or included as part of other marks as long as other elements found in the applied signs may give them sufficient distinctiveness, or provided they are used for informative purposes ${ }^{86}$.

\footnotetext{
${ }^{83}$ MARAVI, Alfredo. "The gastronomic creations as protection object for the Copyright: Possibilities and expediency". In: Andean yearbook of Intellectual Rights $\mathrm{N}^{\circ} 09$, p. 119, 120. (Author translation, original in Spanish).

${ }^{84}$ RAMIREZ, Luis. "Peruvian gastronomy and Industrial Property: Comments about the sigh of Lima and its inclusion in marks records in the exterior". In: Juridical magazine Thomson Reuters. Year 1, N ${ }^{\circ}$ on January 4, 21, 2013, p. 39 to 41. (Author translation, original in Spanish).

${ }^{85}$ Resolution N ${ }^{\circ}$ 20065-2011/DSD-INDECOPI of December 16, 2011

${ }^{86}$ Resolution № 031-2009/TPI-INDECOPI dated January 14, 2009, also gathered from Resolution N`0117-2010/TPIINDECOPI dated January 15, 2010.
} 
Thus, we can appreciate the presence of denominations that identify a dish or element of gastronomy, as well as allusive phrases as to the national origin of a prepared meal, or phrases from a language other than Spanish in restaurant services. In all these cases, the mere presence of these elements should not be sufficient reason for exclusive appropriation, so that absolute grounds for refusal found in legislations of each country are enough to either refuse such records or make the precision that they are not claimable. However, and given the number of citizens in the member countries of the Pacific Alliance, we cannot rule out the intention to obtain trademark registrations in other countries of the Alliance and other countries not members, and thus create undue distortions in the market on terms they should be free to use and not claimable exclusive ownership.

\subsection{Accession, implementation and impact of treaties administered by the World Intellectual Property Organization (WIPO).}

In the framework of implementation of treaties administered by the World Intellectual Property Organization (WIPO), to ensure harmonisation and simplification of registration procedures, figure the accession and implementation of the Madrid Protocol relating to the procedure of international registration of marks with effect in the Member States which have been designated ${ }^{87}$. As for the Pacific Alliance, only Colombia and Mexico have joined the Treaty, which entered into force on 29 August 2012 and February 19, 2013 respectively ${ }^{88}$.

Although the accession to this Protocol could have emerged due to the signature of free promotion treaties with other countries (as happened in the Colombian case), critics has arisen concerning the amount of Colombian and Mexican applications sent abroad compared with the amount of incoming applications and the impossibility to conduct preliminary searches by national attorneys ${ }^{89}$.

We cannot disregard a possible reduction of workload among intellectual property attorneys in each country as applications will not be filed any longer on a national level, as usual. Although it could also be an opportunity to reconfigure existing business models in legal practice, we consider important to take into account the assessment of the impact of Madrid Protocol within the framework of the Pacific Alliance, especially for those countries that still do not have signed such as Peru and Chile, and evaluate the measures to be taken to educate internally about the impacts among all the private and/or government parties involved..

\subsection{Implementation of previous international trade agreements}

As indicated above, almost all members of the Pacific Alliance have agreements with the United States and the European Union. Besides, three of the four founding members are part of the TPP, so that they share the duty to implement their obligations under those agreements.

\footnotetext{
${ }^{87}$ http://www.wipo.int/treaties/es/registration/madrid protocol// (Review: July 18, 2016). For more information about the Madrid Agreement and Madrid Protocol, http://www.wipo.int/treaties/es/registration/madrid/summary madrid marks.html (Review: July 18, 2016).

${ }^{88} \mathrm{http}: / /$ www.wipo.int/treaties/es/ShowResults.jsp?lang=es\&treaty id=8 (Review: July 18, 2016).

89 As mentioned by BERNAL RAMIREZ, after verifying journalistic and WIPO's statistic information as for August 14 , 2013, 3000 applications were received in Mexico, while only 35 Mexican applications were sent abroad, and Colombia was designated in 472 foreign trademark applications while the country has only filed 1 trademark application (BERNAL RAMIREZ Edwin Jesith. Implicaciones del protocolo de Madrid en el derecho marcario de la Comunidad Andina de Naciones. En: http://revistas.uexternado.edu.co/index.php/propin/article/view/3588/3805, Review: July 18, 2016). See also the information contained in: http://www.larepublica.co/asuntos-legales/el-protocolo-de-madrid-un-a\%C3\%B10-ysin-los-resultados-esperados 65901 (Review: July 18, 2016).
} 
In section II of this paper we have shown that countries of the Pacific Alliance had failed to implement its obligations so far with respect to the limitation of liability of Internet providers, which is also included in its agreements with the United States of America and in the TPP.

In this regard, this obligation consists of articulating a policy framework on the matter to ensure that there are legal remedies available for copyright holders against infringements as well as establish or maintain limitations concerning online services corresponding to Internet service providers ${ }^{90}$, which does not imply that such providers are responsible for monitoring their systems in order to prevent any infringing act.

In addition, member countries of the Pacific Alliance will have to implement provisions on the protection of test data for biological products, protection of designations of origin, geographical indications, and indications of provenance, distinctive products, collective marks and certification marks. In that sense, the Pacific Alliance should be a platform for member countries to share experiences on the implementation of those obligations, not only with respect to policy development involving such implementation, but also on the internal work that has been done so that the measure is internalized by civil society.

${ }^{90}$ Transpacific Partnership Agreement. - Article 18.82: Legal resources and Limitations. 


\section{ASPECTS ON INTELLECTUAL PROPERTY TO BE DEVELOPED WHITHIN THE FRAMEWORK OF THE PACIFIC ALLIANCE}

In previous chapters we have reviewed the trading schemes of countries of the Pacific Alliance in which intellectual property was included as sensitive issue, as well as the common problems these countries have and that could be dealt with under a pragmatic approach.

Now, we will develop how intellectual property has been considered in the Pacific Alliance. We will evaluate if it has been enough, and then we will give some proposals that could be collected in future summits and declarations.

\subsection{An agenda under construction}

Unlike other issues present during the formation of this bloc, intellectual property has gradually appearing on the agenda.

The Declaration of Lima of April 28, 2011 established as first stage the prioritization of works in movement of business people and facilitation for the transit migration, including the cooperation police; trade and integration, including facilitation of trade and customs cooperation; services and capital, including the possibility of integrating the stock exchanges; cooperation and mechanisms of solution of differences and the creation of technical groups for all these areas ${ }^{91}$

The Declaration of Paranal of June 6, 2012, issued under the presidential summit in which the Framework Agreement of this bloc was signed, 14 working points were established, related to the elimination of tariffs and rules of origin regime dispute settlement system of electronic certification of origin, interoperability of single contact and mutual recognition of authorized economic operator, sanitary and phytosanitary measures, technical barriers to trade, platform for student mobility and academic, joint activities cultural, integration in trade of services and capital in the region, services and investment, liberalization of migration flows, streamlining flows of people, actions for the promotion of goods and services, and cooperation and exchange of experiences in good regulatory practices improvement on tools that promote productivity, competitiveness, and economic development ${ }^{92}$.

During the first stages of formation, intellectual property was not mentioned. However, there is a change during the following presidential summits.

During the Cadiz Declaration on November 17, 2012, the creation of committees to discuss regulatory reforms and intellectual property as part of the integration process and determine the focus and content that could be incorporated into these new materials was highlighted. ${ }^{93}$

The continuation of exploratory works on these new topics was highlighted in the Declaration of Santiago on January $27,2013^{94}$, and within the framework of the Declaration of Cali on May 23, 2013, the corresponding working group was instructed to prepare and implement a work plan of joint and specific actions of cooperation among intellectual property offices to share experiences and extend cooperation and

\footnotetext{
${ }^{91}$ https://alianzapacifico.net/? wpdmdl=1329 (Review: June 6, 2016).

92 https://alianzapacifico.net/? wpdmdl=1341 (Review: June 6, 2016).

${ }^{93}$ https://alianzapacifico.net/? wpdmdl=2074 (Review: June 6, 2016).

${ }^{94}$ https://alianzapacifico.net/? wpdmdl=2081 (Review: June 6, 2016).
} 
communication links to make better use of the intellectual property system for the benefit of theirs users ${ }^{95}$.

Furthermore, the Declaration of Cartagena de Indias on February 10, 2014, includes a mandate for the intellectual property group to identify in the short term activities in cooperation in industrial property and copyrights, giving priority to those areas with the greatest impact on the regional integration process ${ }^{96}$.

Although no mention was made in the Declaration of Punta Mita on June 20, 2014, the Declaration of Paracas on July 3, 2015, contains a mandate for the intellectual property working group to set a pilot program technology platform for dissemination of information and technology transfer, as well as workshops and seminars to exchange experiences and information among IP offices of member countries.

Finally, a Joint Declaration of Intellectual Property Offices was issued on October 8, 2015 in Geneva, Switzerland, in which 3 topics concerning patents, trademark registration and technology transfer were agreed, as set forth below:

1. "To facilitate the realization of rapid, inexpensive and high-quality patent examinations, to expedite the proceedings for the applicants, while reducing the workload of the four offices through mechanisms to benefit from the work examinations by other offices.

To fulfil the first objective, the Office of Industrial Property of Chile, Colombia, Mexico and Peru intend to sign an agreement that will allow the expedited procedure of applications $A P$, having obtained a favourable decision in any other office of the Alliance Pacific, also known as Patent Prosecution Highway (PPH)

2. To explore possible measures to harmonization and simplification of procedures in the trademark field, so that useful information is provided in the early stages of processing, while save time and reduce transaction costs for potential trademark registration in Chile, Colombia, Mexico and Peru. Among such measures, the Offices consider implementation of standard forms, among the four countries, to apply for trademark registrations.

3. According to the Presidential Declaration of Paracas, offices will materialize the pilot program of the technology platform for information dissemination and technology transfer program as well as workshops and seminars to exchange experiences and information, 97 .

While the issue of Intellectual Property posteriorly emerged as an important development for the integration bloc factor, also it became necessary to establish common ground, so the agenda is in successive construction, feedback and improvement.

From our point of view, the decision not to establish provisions for intellectual property within the framework of the Pacific Alliance could be justified by the fact that country members have already high regulatory standards, given the signature of previous agreements such as the ones signed with United States of America and the European Union. Besides, 3 of these 4 countries (Chile, Mexico and Peru) were negotiating the Transpacific Association Treaty (TPP its acronym in English) which establishes new provisions in intellectual property. Thus, it was not necessary to replicate such provisions within the framework of the Pacific Alliance.

\footnotetext{
${ }^{95}$ https://alianzapacifico.net/? wpdmdl=2084 (Review: June 6, 2016).

${ }^{96}$ https://alianzapacifico.net/? wpdmdl=2086 (Review: June 6, 2016).

${ }^{97}$ https://alianzapacifico.net/? wpdmdl=5417 (Review: June 6, 2016) Self-made translation.
} 
Notwithstanding, we should take into account that this agreement is open to the accession of new members who may not necessarily have the same standards of protection of intellectual property rights.

On the other hand, country members of the Pacific Alliance have not taken the opportunity to include provisions on intellectual property matters that are of common interest such as the use of genetic resources or the protection of traditional knowledge, which in many cases developed countries agree not to include as key issues concerning the protection of intellectual property or include them with obligations aimed to cooperation such as granting of information. The Trade Promotion Agreement between Peru and United States of America gives an important step for the protection of traditional knowledge. In the Memorandum of Understanding on Biodiversity and Traditional Knowledge, signed within the framework of that agreement, the countries recognized the importance of protecting traditional knowledge; however, no obligations to constrain the granting of patents to the disclosure of the source or country of origin of traditional knowledge or genetic resource that was used in the invention were established $^{98}$.

Usually, during negotiations between a developed country and a developing (or emerging) country, these issues are addressed in parallel letters to the trade agreement, without these letters being included as part as that agreement; that was the case of the agreement between Peru and the United States of America, and the agreement between these two countries on biodiversity and traditional knowledge understanding.

The Pacific Alliance is, from our perspective, the appropriate framework for the development of these issues, especially since, as noted above, Chile, Mexico and Peru, in parallel, were negotiating the TPP in which they have incorporated provisions on traditional knowledge, although not directly in the chapter on intellectual property, in part on cooperation, marking an important precedent. This bloc then offers an opportunity to change the scheme usually impose by United States of America and the European Union, among other powers, to develop rules on Intellectual Property and, therefore, through the establishing of provisions covering their interests on the subject.

\subsection{The model to be follow: regulation or cooperation?}

We believe that the implementation of a chapter of intellectual property in the Pacific Alliance should follow the aims pursued by the bloc that is, a community of pragmatic interests and strategic regionalism "out" or open regionalism. Thus, efforts should be geared so that existing intellectual property and assets of this kind to exist in the future in the bloc could generate a value in the globalized world.

Given the adherence to various conventions administered by the World Intellectual Property Organization (WIPO) and the signing of trade agreements with various countries and economic blocs, each of the member countries of the Pacific Alliance has already own regulations related intellectual property. As for Colombia and Peru, they already maintain common legal standards as part of the Andean Community, so generating more legislation on the matter would not be necessary and could be redundant, or could generate problems in its implementation, especially if there is a need to change rules of the Andean Community, which also apply to countries like Ecuador and Bolivia, which are not members of the group.

\footnotetext{
${ }_{98}$ BOZA, Sandy and ROCA, Santiago. "Biodiversity and traditional knowledge in the Agreement of Commercial Promotion Peru - the United States " in Intellectual property and commerce in Peru: impact and hanging agenda, ESAN Editions, 2007, Lima, p. 206. (Author translation, original in Spanish).
} 
Nevertheless, and given the existence of common points among the country members arising from the characteristics and situation on enforcement of intellectual property rights, we see that a framework for cooperation is justified. We do not rule out that there may be some kind of legislation, but it will be according to the evolution of the agenda, to the common points that countries may have in the future, and need to strengthen and complement national or community existing legislation on intellectual property, and if possible, reduce the costs incurred in protecting intangible assets.

The working group on intellectual property of the bloc has noted that the sociocultural characteristics the member countries are a clear advantage for development of industries related to intellectual property advantage, so that areas of cooperation this matter are explored ${ }^{99}$. Analyzed ad tested cooperation projects are grouped into three areas (copyright, industrial property and cross-cutting issues) in the aim at strengthening intellectual property systems in the region and provide system users access to information and services provided by the competent authorities of each country $^{100}$.

Thus, the measures taken in the Geneva Declaration relating to procedures for patents and trademark registration respond to provide users access to the services provided by the competent authorities of each country, while the action taken in relation to the pilot program technological platform for the dissemination of information and technology transfer responds to provide users access to the services provided by the competent authorities of each country responds to strengthen the intellectual property system and facilitate access to information by the competent authorities.

\subsection{Implementing cooperation}

Following the aforementioned areas in which the cooperation is analyzed and evaluated, we can provide various proposals, taking into account no longer a framework for harmonization of legislation, but a framework for harmonization of processes to obtain industrial property rights or recognition a right of existing copyright.

Thus, the measures taken in the Geneva Declaration are oriented only to industrial property matters (registration of trademarks and patents). However, it is also possible to harmonize the formats used in copyright issues for obtaining the registration of a work before a national competent authority, based on the common information set for all works (the author, the holder other than the author from a contract, transfer mortis causa or legal presumption, the work and the details of your publication or character of unpublished) or other information or documentation relevant in each particular case (the source code, user manuals, information about the producer in the case of computer programs; or information about the phonogram producer and performers, in the case of musical works and phonograms records, etc.)

Similarly, in relation to copyright enforcement, it is possible to strengthen coordination to share experiences and take joint actions to reduce levels of piracy, both at unauthorized copies and infringements through digital media. This coordination should be made among administrative, police and judicial authorities, including prosecutors. These cooperation measures include awareness activities carried out in the public about the effects of piracy in the cultural industries and entertainment of each of the member countries of the bloc.

\footnotetext{
${ }_{100}^{99} \mathrm{https}$ ://alianzapacifico.net/temas-de-trabajo/ (Review: June 6, 2016). 
These cooperation activities should be carried simultaneously with activities to specialize and train officials from the bloc, as well as lawyers and people of cultural and entertainment activities under the patronage of the Pacific Alliance or through joint efforts with the World Intellectual Property organization (WIPO).

Moreover, it is important that these countries also undertake cooperation activities that allow them to implement obligations derived from other trade agreements signed with third parties. For example, the member countries of the Pacific Alliance must make arrangements with the purpose of implementing the provisions on limitations on the liability of service providers which have been included in the agreements they have with the United States and in the framework of TPP.

Furthermore, with regard to the protection of biotechnology and collective knowledge, it should focus on the exchange of experiences that determine the possibility of assessing novelty of inventions with a broader approach and alert to prevent undue obtaining patents that may affect third party interests and thereby, avoid incurring such third parties in litigation costs to seek the annulment of such patents.

With regard to international protection of country marks, members of the Pacific alliance should seek the recognition of symbols or signs used in each country member, regardless of the discussion about the protection granted to marks formed or including names of any State ${ }^{101}$. Despite the existence of many registrations, marks could be used in different forms over time, depending on the image countries wishes to present, maintain or renew, so country members should seek ways to reduce costs in the trademark protection offered by a territorial registration in a particular class of good/services. In that sense, country marks could be recognized as officials during future summit declarations. In parallel, country members could take actions to promote proper use of country marks and promote the discussion in WIPO panels.

With respect to signs consisting of names that identify elements of national and international cuisine, country members should focus on exchanging experiences without generating changes in industrial property legislation. Such experiences should be aimed at protecting those names against any attempt to claim them exclusively through trademark registration. Thus, country members should share cases studies, list of items that make up the cuisine of each of the member countries, as well as elements that can be commonly identified as part of international cuisine, and exchange information in ongoing trademark applications to assess if the applied sign could be registered. These signs should be evaluated based on existing absolute grounds for refusal (lack of distinctiveness, genericity, descriptiveness, usual terms or frequently used).

Finally, since we are mentioning trademark issues, country members should share experiences that may arise from protection of old-factory signs, hearing, cancellation or revocation of a mark by becoming generic, and the impact of adherence of Madrid Protocol among countries that are already members (Colombia and Mexico) and the possible impact on countries pending for adherence (Chile and Peru).

\footnotetext{
${ }^{101}$ For reference, the Chilean Industrial Property Law (Law No. 19.039) provides in Article 20 paragraph a) that it cannot be registered as trademarks the names or abbreviations of any State. This prohibition is not contemplated under Mexican law, and in the case of the Community rules applicable to Colombia and Peru, there is no prohibition either except for these situations: a) if the sign describes the geographical origin of the product or service for which will be used to generate deception on the origin of the product or service; $b$ ) if the sign contains or imitates an appellation of origin and generate confusion or imply unfair advantage of its reputation, c) if the sign contains a protected designation of origin for wines and spirits, d) if the sign consists of a domestic or foreign geographical indication and is likely to cause confusion to the products or services to which it applies. See as reference Resolution No. 529-2007 / TPIINDECOPI dated March 15, 2007, regarding the application for registration of the word mark MONACO, to distinguish entertainment, gambling, casinos, slot Class 41 of the International classification.
} 


\subsection{Establishing a regulatory agenda}

While cooperation should guide the group's agenda on intellectual property of the Pacific Alliance, country members could also analyze the need to start to negotiate certain provisions on matters of common interest that have been difficult to incorporate them in other agreements. Matters on traditional knowledge could be a good example given that Chile, Colombia, México and Peru in some free trade agreements have provisions on that subject in the field of cooperation, it would be important to be able to establish specific and deeper obligations under the Pacific Alliance, which allow them to have adequate protection for these products.

Constitute a normative basis on these matters would be important as it will be the four country founders of the Pacific Alliance members which establish the rules, without being subject to pressures by any other third party. Bearing in mind that there are 42 observers of this process of integration, which are potential candidates (including those found in developing and developed countries), it would be desirable to establish the standards that these four countries want the future members adhere meet to protect their interests. To establish these regulations, these countries should also take into account the obligations in other forums and international agreements, in order not to generate incompatibilities that make unfeasible its application.

\section{Conclusions:}

The Pacific Alliance is a process of deep integration, which has great potential, since it represents approximately $50 \%$ of foreign trade in Latin America. In that sense, it has attracted the attention of 42 economies that are observing the process in order to determine its incorporation.

In this context, the founding countries (Chile, Colombia, Mexico and Peru) have the opportunity to develop disciplines to address their interests and concerns. This advantage is very useful in a scenario in which, following the deadlock in negotiations at the multilateral level, the major powers have set the negotiating agenda, especially in the field of protection of intellectual property, imposing structure and content of obligations on this sensitive matter.

Since the WTO negotiations on intellectual property, have not only been delayed due to the reluctance of many countries to incur in greater obligations on the matter, but also because of the sensitivity of issues such as the relationship between intellectual property with public health, biodiversity and traditional knowledge, countries with higher exports of intellectual property assets incorporated in free trade agreements (bilateral, multilateral) arrangements that give them greater protection, so that it was not possible that developing or emerging countries could include in all cases provisions of their own interests.

The countries of the Pacific Alliance have been no exception and have assumed with countries like the United States and the European Union obligations TRIPS plus (although to a lesser extent). Although such obligations also benefit them, they do not develop in depth issues that are of their interests. As explained in this paper, Chile, Colombia, Mexico and Peru face many common problems in intellectual property such as the fight against piracy and counterfeiting, but also have common interests such as the protection of the country marks, biodiversity and traditional knowledge.

In this sense, given that these countries decided to promote the development of issues on intellectual property in the framework of the Pacific Alliance, they have the great possibility to set their own agenda to develop cooperation activities or long-term 
international regulation to address their problems and interests and culminate with the implementation of their obligations under other international trade agreements of which they also take part.

Pacific Alliance is a unique opportunity these countries have to break the structure and scheme other countries or economic blocs imposed in negotiating previous international trade agreements. Now these countries can impose an own scheme to be accepted by future members. 